\title{
Early-Life Origins of Metabolic Syndrome: Mechanisms and Preventive Aspects
}

\author{
Chien-Ning Hsu ${ }^{1,2}{ }^{\mathbb{D}}$, Chih-Yao Hou ${ }^{3} \mathbb{D}$, Wei-Hsuan Hsu ${ }^{4} \mathbb{D}$ and You-Lin Tain ${ }^{5,6, *(\mathbb{D})}$ \\ 1 Department of Pharmacy, Kaohsiung Chang Gung Memorial Hospital, Kaohsiung 833, Taiwan; \\ cnhsu@cgmh.org.tw \\ 2 School of Pharmacy, Kaohsiung Medical University, Kaohsiung 807, Taiwan \\ 3 Department of Seafood Science, National Kaohsiung University of Science and Technology, \\ Kaohsiung 811, Taiwan; chihyaohou@webmail.nkmu.edu.tw \\ 4 Department of Food Safety/Hygiene and Risk Management, College of Medicine, \\ National Chen Kung University, Tainan 701, Taiwan; whhsu@mail.ncku.edu.tw \\ 5 Department of Pediatrics, Kaohsiung Chang Gung Memorial Hospital and Chang Gung University \\ College of Medicine, Kaohsiung 833, Taiwan \\ 6 Institute for Translational Research in Biomedicine, Kaohsiung Chang Gung Memorial Hospital \\ and Chang Gung University College of Medicine, Kaohsiung 833, Taiwan \\ * Correspondence: tainyl@cgmh.org.tw; Tel.: +886-975-056-995; Fax: +886-7733-8009
}

check for

updates

Citation: Hsu, C.-N.; Hou, C.-Y.; Hsu, W.-H.; Tain, Y.-L. Early-Life Origins of Metabolic Syndrome:

Mechanisms and Preventive Aspects. Int. J. Mol. Sci. 2021, 22, 11872. https://doi.org/10.3390/ ijms222111872

Academic Editors: Manfredi Rizzo, Anca Pantea Stoian and Ali Abbas Rizvi

Received: 22 October 2021

Accepted: 31 October 2021

Published: 2 November 2021

Publisher's Note: MDPI stays neutral with regard to jurisdictional claims in published maps and institutional affiliations.

Copyright: (c) 2021 by the authors. Licensee MDPI, Basel, Switzerland. This article is an open access article distributed under the terms and conditions of the Creative Commons Attribution (CC BY) license (https:/ / creativecommons.org/licenses/by/ $4.0 /)$.

\begin{abstract}
One of the leading global public-health burdens is metabolic syndrome (MetS), despite the many advances in pharmacotherapies. MetS, now known as "developmental origins of health and disease" (DOHaD), can have its origins in early life. Offspring MetS can be programmed by various adverse early-life conditions, such as nutrition imbalance, maternal conditions or diseases, maternal chemical exposure, and medication use. Conversely, early interventions have shown potential to revoke programming processes to prevent MetS of developmental origins, namely reprogramming. In this review, we summarize what is currently known about adverse environmental insults implicated in MetS of developmental origins, including the fundamental underlying mechanisms. We also describe animal models that have been developed to study the developmental programming of MetS. This review extends previous research reviews by addressing implementation of reprogramming strategies to prevent the programming of MetS. These mechanism-targeted strategies include antioxidants, melatonin, resveratrol, probiotics/prebiotics, and amino acids. Much work remains to be accomplished to determine the insults that could induce MetS, to identify the mechanisms behind MetS programming, and to develop potential reprogramming strategies for clinical translation.
\end{abstract}

Keywords: cardiovascular disease; obesity; hypertension; oxidative stress; metabolic syndrome; dyslipidemia; insulin resistance; diabetes; nutrient sensing; developmental origins of health and disease $(\mathrm{DOHaD})$

\section{Introduction}

Metabolic syndrome (MetS) is not a single disease but a collection of medical conditions that occur together and increase the risk of cardiovascular disease (CVD). Although MetS had been defined slightly differently by various organizations [1], the main components of MetS include obesity, hypertension, dyslipidemia and insulin resistance. The prevalence estimates vary, based on the criteria used for the diagnosis of MetS. Thus far, global MetS prevalence is estimated to affect approximately one quarter of the world population [2]. More importantly, MetS-related disorders account for two thirds of the non-communicable disease (NCDs) deaths [3]. Also important is that it displays multiple and diverse phenotypes with indications for differing treatment strategies. In the absence of specific therapeutic regimens, the prevalence of MetS remains on the increase globally [2]. Therefore, a superior strategy to stop the spread of the MetS epidemic is required to for prevention, in addition to treatment. 
Most NCDs may start in early life [4]. The establishment of various adverse environmental conditions, which takes place during pregnancy and lactation, could be involved in the early-life programming of health. This concept is now known as the developmental origin of health and disease $(\mathrm{DOHaD})[5]$, which is supported by evidence coming from a large number of epidemiological and experimental observations.

Various early-life risk factors often linked to nutritional imbalance may lead to vulnerability to later MetS [6-10]. Remarkably, there is evidence for the programming of some similar features of MetS from different early-life insults, possibly suggesting a commonality of mechanism and highlighting that identifying underlying mechanistic pathways is vital to develop ideal prevention interventions [6]. By intervening before disease ever occurs, we have the potential to stop undesirable programming processes resulting in MetS, which is referred to as reprogramming [11].

Our review aims to map the key concepts in the developmental programming of MetS. Hence, we first highlight epidemiological studies that link early-life factors to MetS of developmental origins. This is followed by a summary of the potential developmental mechanisms behind the origin of MetS. Furthermore, we present a summary of reprogramming interventions from animal studies that can prevent the development of MetS.

Our search strategy was designed to retrieve published manuscripts in the English language from January 1980 to September 2021 relating to MetS and DOHaD from the PubMed/MEDLINE databases. We used different combinations of the following search terms: "cardiovascular disease", "cardiometabolic disorder", "developmental programming", "DOHaD", "reprogramming", "dyslipidemia", "hyperlipidemia", "obesity", "diabetes", "insulin resistance", "hyperglycemia", "hypertension", "mother", "father", "paternal", "pregnancy", "gestation", "offspring", "progeny", and "metabolic syndrome". Additional papers were then selected and evaluated on the basis of fitting references in eligible literature.

\section{Epidemiological Evidence Linked Early-Life Insults with Offspring MetS}

Extensive epidemiological studies have linked adverse early-life conditions with the risk of MetS in the offspring in later life. First, there is evidence from severe famines [12-16]. The Dutch Famine Birth Cohort Study demonstrated that the children of pregnant women exposed to famine displayed various characteristics of MetS, like obesity, dyslipidemia, hypertension, insulin resistance and CVDs [12,13]. Findings similar to those of the Dutch famine were also established in other famine studies [14-16]. Of particular interest, maternal undernutrition during early gestation had greater effects in increasing cardiometabolic risk in adult offspring, compared to maternal undernutrition during middle- or lategestation [12]. Another line of evidence comes from research in twin pregnancy. These studies reported there were associations between low birth weight (LBW) and different characteristics of MetS, including hypertension, type 2 diabetes and insulin resistance [17,18]. Third, a prior systematic review of 39 studies revealed that rapid postnatal catch-up growth of LBW neonate had an approximately $80 \%$ increased risk for CVDs, a major complication of MetS [19]. The risk factors for MetS of developmental origins have been assessed in a number of observational studies. Risk factors reported in these cohorts relating to adverse cardiometabolic outcomes in adult offspring include maternal obesity $[20,21]$, gestational diabetes [21,22], excessive postnatal weight gain, in [23] and environmental chemicals exposure [16]. To date, literature on paternal risk factors is scare. There is emerging evidence that paternal risk factors, such as obesity, diabetes mellitus, advanced age, and cigarette smoke are associated with adverse metabolic and cardiovascular outcomes in their offspring [24,25]. All of these observations provide links between the suboptimal early-life environment and the risks for developing MetS in adulthood.

However, these epidemiological studies do not propose molecular mechanisms underlying programming processes for the development of potential reprogramming interventions. Therefore, animal models have been established to demonstrate the biologi- 
cal plausibility of the associations observed in epidemiological studies, providing proof of causality.

\section{Animal Models for Developmental Origins of MetS}

In view of the difficulties in establishing animal models that manifest all the characteristics of MetS, most investigations into MetS of developmental origin are done using models that display certain hallmarks of MetS [6-8]. To date, a broad range of adverse early-life environmental factors are associated with certain features of MetS in adult offspring, including nutrition imbalance, maternal conditions or disease, chemical exposure, medication use, etc. [6-10,26-29]. However, excessive information is available based on only one characteristic of MetS, and in the interest of brevity, we have limited this review to at least two of the listed components that are present [30-72] (See Table 1). Diverse smalland large-animal models have been developed for $\mathrm{DOHaD}$ research $[29,73]$, each with its own natural advantages and disadvantages. This review was restricted to rodent models for appropriate comparisons of major characteristics of MetS appear through a lifetime. Table 1 reveals the outcomes relating to MetS determined in rats ranging from eight weeks to one year of age. Considering one human year is almost equivalent to two rat weeks in adulthood [74], most outcomes are determined from childhood to middle adulthood in terms of human age. Each category is discussed in turn.

\subsection{Nutritional Imbalance}

Studies of nutritional programming linking DOHaD-related disorders using animal models have been ongoing since the early 1990s [73]. Dietary manipulation has been the focus of a large body of work relating to MetS of developmental origins. Table 1 shows insufficient or excessive consumption of a certain nutrient has been used to induce different features of MetS. Following the studies of the Dutch famine [12,13], a number of maternal nutrient restriction models have been established to mimic the undernutrition experienced by pregnant women at that time.

Caloric restriction is defined as an overall reduction in energy and nutrient intake without incurring specific nutrient. In rats, a 50\% caloric restriction during gestation and lactation can result in hypertension and insulin resistance in adult offspring [28-30]. Restriction of calories by a range of $30 \%$ to $70 \%$ in pregnant rats has been reported to induce increases of BP in their adult progeny, as reviewed elsewhere [74]. From a general perspective, offspring exposed to a greater degree of caloric restriction are prone to develop hypertension earlier [75]. However, the extent to which the severity of caloric restriction affects other characteristics of MetS in adult offspring remains to be elucidated further.

Similar to caloric restriction, the protein restriction model may mimic the challenge faced in developing nations. Adult rat offspring born to dams exposed to protein restriction during pregnancy develop hypertension [31] and insulin resistance [32]. Although a more severe protein restriction causes an earlier development of hypertension in offspring [75], a previous study reported that two low-protein diet manipulations with the same protein concentration ( $9 \%$ ) but different components in pregnant rat provoked different programming effects on BP in adult offspring [76]. It is therefore possible that the balance of specific amino acids and other nutrients may be a critical determinant in programming of MetS-related phenotypes but not protein restriction per se. 
Table 1. Rodent models of MetS of developmental origins, categorized according to environmental factors.

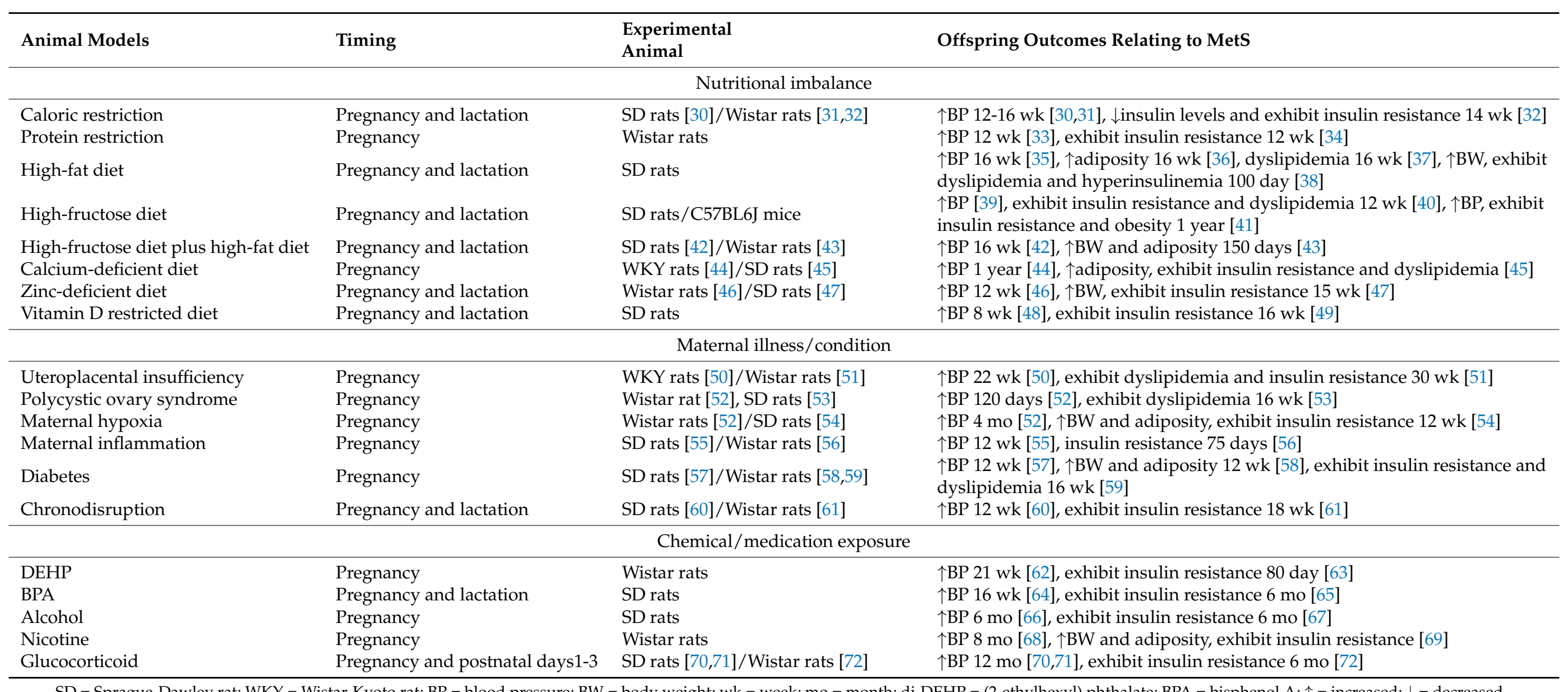

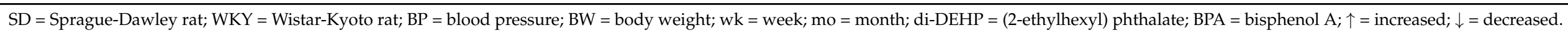


Table 1 indicates maternal high-fat diet programs almost all feature of MetS in adult rat offspring at 14-16 weeks of age, such as hypertension [33], obesity [34,36], dyslipidemia $[35,36]$, and insulin resistance [36]. A high-fat diet has been widely used to explore the mechanisms of metabolic disease of both established and developmental origins [77,78]. Nevertheless, the programming effects of maternal high-fat diet on offspring BP are diverse according to age, sex, strains, and different fatty acids compositions [78]. Notably, abnormal regulation of insulin signaling and lipid metabolism programmed by a maternal high-fat diet can be promoted by a post-weaning high-fat diet, leading to development of MetS-related phenotypes in adult offspring $[37,79,80]$. A maternal high-fructose diet has also been reported as a commonly used animal model for studying MetS of developmental origins [81]. We and others have shown that adult rat offspring of mothers exposed to $60 \%$ high-fructose diet during gestation and lactation displayed MetS-related comorbidities [39-41,81]. Furthermore, mother rats receiving a high-fructose diet plus a high-fat diet saw an elevation in BP and BW in their offspring [42,43]. These findings suggest that maternal diets containing key components based on the human Western diet may have synergistic effects between fat and sugar on the development of features of MetS in adult offspring. Moreover, deficiencies in micronutrients, including calcium [44,45], zinc [46,47], and vitamin $\mathrm{D}[48,49]$ in pregnant mother rats are associated with offspring MetS.

\subsection{Maternal Illnesses and Conditions}

Complications during pregnancy and maternal diseases can affect fetal programming, resulting in intrauterine growth retardation (IUGR) in offspring [82]. As IUGR reflects an abnormal adaptive fetal growth in an adverse intrauterine environment, IUGR animal models are applied to decipher the underlying mechanisms behind MetS of developmental origins [82]. In the model of uteroplacental insufficiency developed by uterine artery ligation in the pregnant rat, IUGR offspring developed hypertension, dyslipidemia and insulin resistance in adulthood [50,51]. Additionally, several animal models resembling maternal conditions and diseases have been evaluated, such as polycystic ovary syndrome (PCOS) [52,53], maternal hypoxia [52,54], maternal inflammation [55,56], diabetes [57-59], and chronodisruption $[60,61]$.

Epidemiological observations have established that inflammatory disorders, PCOS, and hypoxia increase the risk of pregnancy complications [83,84]. In the PCOS model, maternal hyperandrogenemia was induced by injection of testosterone cypionate in late gestation for studying cardiometabolic outcomes in adult offspring. Accordingly, adult offspring exhibited hypertension and dyslipidemia at 16-17 weeks of age [52,53]. Likewise, several features of MetS can be programmed by maternal hypoxia and inflammation, including hypertension [52,55], obesity [54], and insulin resistance [54,56].

It is clear from a range of human observational studies that maternal diabetes gives rise to different phenotypes of MetS in offspring, including obesity, insulin resistance, hypertension, dyslipidemia, and CVDs [85]. The majority of rodent studies of maternal diabetes have employed streptozotocin (STZ)-induced diabetes [57-59]. When injected into neonates $[57,58]$ or adult rats $[57,59]$, STZ can cause type 1 or type 2 diabetes, respectively. Almost all major characteristics of MetS are present in adult offspring born to diabetic mothers at 12-16 weeks of age [57-59], which are largely in line with the findings in humans.

There is now increasing evidence connecting disturbances in the circadian rhythm with the key components of MetS [86]. A meta-analysis including 22 studies showed that overall sleep quality as well as sleep complaints have significant positive associations with MetS [87]. The circadian system is the major regulator of human metabolism [88]. The circadian clock system consists of central and peripheral clocks, which are coordinated to produce daily rhythms [89]. This central clock located in the suprachiasmatic nucleus regulates the body's metabolism through synchronizing peripheral clocks in our body's key organs such as the heart, kidney, liver, muscle and adipose tissue [90]. Accordingly, it is not surprising that circadian rhythm sleep disorders have been linked to several components of the MetS [86]. 
In pregnant women, circadian disruption can lead to a wide range of adverse consequences for their children [91]. Maternal circadian disruption affects not only central and peripheral circadian clocks but also a range of endogenous circadian signals including melatonin and glucocorticoid secretion $[92,93]$. Although data on maternal sleep disorder programs MetS in offspring remain limited, two animal studies have reported that adult rat offspring born to dams received constant light exposure or pinealectomy developed hypertension [60] and insulin resistance [61].

\subsection{Chemical and Medication Exposures}

Relatively few studies have investigated early-life chemical and medication exposures on developmental programming of MetS. A broad range of early-life environmental chemical exposures have been related to increased risk for developing hypertension of developmental origins, as we reviewed elsewhere [94]. These chemicals, di-(2-ethylhexyl) phthalate (DEHP) and bisphenol A, have been studied for their impact on insulin resistance in adult progeny $[63,65]$. These findings are in agreement with epidemiological research data showing that endocrine-disrupting chemical exposure is linked to CVDs later in life [95].

As with chemical effects during development, substance abuse is another risk factor. A high proportion (6-16\%) of pregnant women in the United States are cigarette smokers, alcohol abusers, or illicit drug users [96]. In rodent models, maternal nicotine or alcohol exposure causes hypertension [66,68], insulin resistance [67,69], and obesity [69] in adult offspring.

Despite a number of medications (such as cyclosporine [97] and minocycline [98]) administered in pregnancy that have been related to developmentally programmed hypertension in adult offspring [29], only glucocorticoid has been studied for other features of MetS [70-72]. During development, the fetus is at risk of glucocorticoid exposure through excess maternal corticosteroids (e.g., stressed pregnancies) or through exogenous administration (e.g., preterm birth). Antenatal or neonatal administration of dexamethasone lead to hypertension $[70,71]$ and insulin resistance [72] in adult rat offspring.

Comparable to maternal programming, reported animal models relating to paternal factors-induced MetS in offspring are rather limited [25]. So far, only adult offspring of paternal low protein intake [99], paternal high-fat diet [100], and paternal hyperglycemia [101] have been evaluated, and these have developed at least two components of MetS.

Considering animal models are in good agreement with the epidemiological observations showing various maternal insults induce similar features of MetS in offspring, it is possible that various insults may mediate common mechanisms culminating in MetS of developmental origins.

\section{Common Mechanisms behind Metabolic Syndrome of Developmental Origins}

Though the common mechanisms behind developmental programming of MetS have not yet been thoroughly identified, animal studies have shed light on potential mechanisms, such as oxidative stress [26,102], aberrant activation of the renin-angiotensin system (RAS) [103,104], gut microbiota dysbiosis [105,106], dysregulated nutrient-sensing signals [26], and glucocorticoid programming [107]. Figure 1 is a graphic depiction of early-life adverse environmental factors that mediate common mechanisms and affect multiple interacting organ systems, resulting in MetS of developmental origins in later life. 


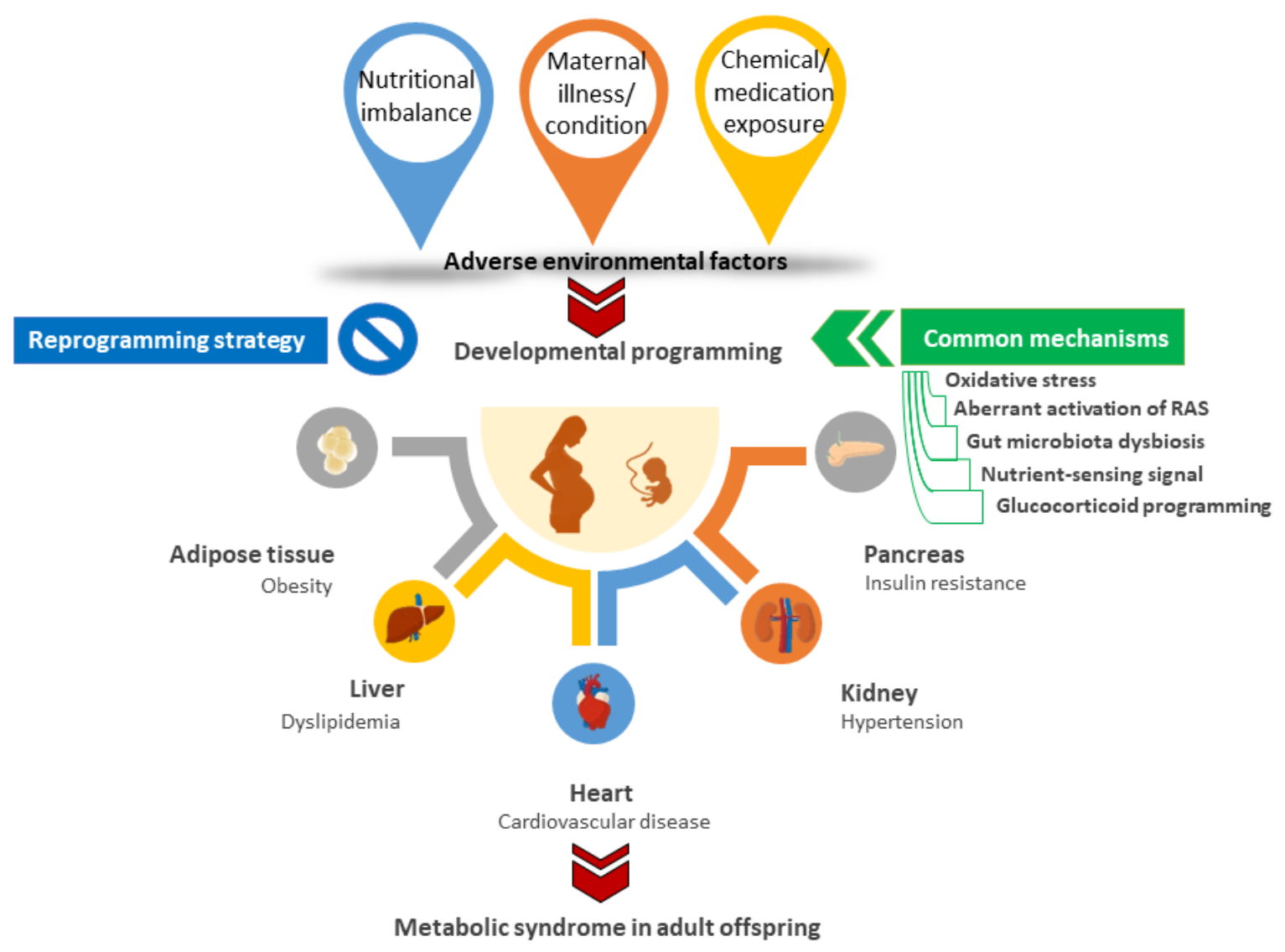

Figure 1. A schematic representation outlining the adverse environmental factors and potential mechanisms that may underlie the developmental programming in different organ systems resulting in metabolic syndrome in adulthood. By switching therapy from adulthood to early life before metabolic syndrome occurs by so-called reprogramming, we have the potential to prevent metabolic syndrome of developmental origins. RAS = renin-angiotensin system.

\subsection{Oxidative Stress}

During development, the fetus is extremely vulnerable to injury to oxidant molecules because of its low antioxidant defense mechanisms [108]. Oxidative stress describes a condition of imbalance in the production of reactive oxygen species (ROS) and the antioxidant defense system, which plays a crucial, mechanistic role in MetS of developmental origins $[6,9,109]$. As reviewed elsewhere [26], a great number of early-life adverse environmental factors can promote oxidative stress resulting in developmental programming, such as: maternal undernutrition, maternal high-fat diet, maternal high-fructose diet, maternal diabetes, preeclampsia, prenatal hypoxia, maternal inflammation, prenatal glucocorticoid exposure, etc. Complete MetS features can be programmed by maternal high-fructose intake in rodent animal models, as reviewed elsewhere [81]. Among them, hypertension [110], insulin resistance [111], and dyslipidemia [112] have been related to oxidative stress. Current evidence indicates that BP regulation, insulin function axis and lipid metabolic pathways could be sensitive targets to oxidative stress programming [26,102].

Additionally, high levels of ROS can reduce nitric oxide (NO) bioavailability. NO deficiency is a key pathogenic mechanism of MetS-related disorders, such as hyperlipidemia, obesity, diabetes mellitus, hypertension, and CVD [113]. NO deficiency can be caused by inhibition by asymmetric dimethylarginine (ADMA, an NOS inhibitor). Emerging evidence supports that the ADMA-NO imbalance plays a crucial role in the pathogenesis of compromised pregnancies and fetal programming [114]. Among the reasons for MetS, oxidative stress has centered attention on ADMA [114]. Prior research has shown increased plasma ADMA levels are related to major characteristics of the MetS, such as dyslipidemia, diabetes mellitus, hypertension and obesity [115]. 
Conversely, several agents with antioxidant properties have shown the potential to prevent MetS of developmental origins. Resveratrol is a polyphenolic compound with antioxidant activity [116]. Resveratrol supplementation during gestation and lactation can benefit low protein diet-induced oxidative stress in adult offspring, combined with alleviating characteristics of MetS [117]. Melatonin is also an antioxidant [118]. Its use in pregnancy and lactation has shown beneficial effects on various adult chronic diseases in later life [118]. Previous studies showed maternal melatonin treatment prevents adult offspring against hypertension, glucose intolerance and insulin resistance [60,61]. In view of the fact that MetS is a multi-organ disease, there will be a growing need to better understand organ-specific redox-sensitive signaling responsible for programming processes for MetS of developmental origins.

\subsection{Aberrant Activation of RAS}

The RAS is both a provider and target to MetS [119]. The classic RAS can be defined by the activity of angiotensin-converting enzyme (ACE) to form angiotensin II (ANG II) and the subsequent activation of the Ang II type 1 receptor (AT1R) to promote vasoconstriction. Activation of the classic RAS in specific cell types that mediate various phenotypes of MetS, including hypertension, hyperglycemia and insulin resistance [104,119].

The most common studied phenotype of MetS related to the RAS is hypertension. A variety of animal models listed in Table 1 have indicated the role of RAS, implicating it in renal programming and hypertension of developmental origins. These models include protein restriction [120], high-fat diet [121], high-fructose diet [122], uteroplacental insufficiency [123], maternal hypoxia [124], maternal inflammation [125], diabetes [126], chronodisruption [60], and glucocorticoid exposure [70]. These findings support the importance of the RAS during critical developmental stage on determining hypertension of developmental origins in later life.

On the contrary, early inhibition of classic RAS shows benefits against hypertension of developmental origins [104]. Additionally, RAS inhibition has been reported to control hyperglycemia, insulin resistance and dyslipidemia in patients with MetS [119]. On the other hand, the alternative ACE2/angiotensin-(1-7)/mitochondrial assembly receptor/Mas axis has been identified as a negative regulator of Ang II activity [127]. Considering activation of ACE2/ANG-(1-7)/Mas axis having therapeutic potential in hypertension of developmental origins [104,128], further studies are required to elucidate its reprogramming effects in other MetS-related phenotypes.

\subsection{Gut Microbiota Dysbiosis}

Development of gut microbiota early in life can impact adult diseases of developmental origins [129]. Imbalance of gut microbiota were related to almost all MetS phenotypes, such as hypertension [81,121], obesity [130], insulin resistance [131], and dyslipidemia [132]. Decreased gut microbial richness and diversity are associated with increased risk of developing CVD [133]. Several adverse environmental factors related to MetS of developmental origins have been reported to cause cardiovascular programming coinciding with abnormalities of gut microbiota, including maternal high-fructose diet [134], maternal high-fat diet [121], and maternal PCOS [52].

During recent years, increasing evidence has been accumulated that gut microbiota dysbiosis causes CVD of developmental origins attributed to increases of trimethylamine$\mathrm{N}$-oxide (TMAO), increases of tryptophan-derived uremic toxins, decreases of short chain fatty acids (SCFAs), and activation of the aryl hydrocarbon receptor (AhR) pathway [106,135-137]. SCFAs can modulate glucose homeostasis, appetite regulation and obesity [138]. Many studies report a positive association between increased TMAO level and Met-related disorders [139]. Additionally, several indole derivatives derived from tryptophan by the microbiota may have a role in MetS pathogenesis via activating AhR signaling [140]. These observations support the notion that gut microbiota metabolites are involved in the pathogenesis of MetS of developmental origins. 
Conversely, early intervention targeting gut microbiota can prevent CVD in later life [106]. To date, reprogramming interventions based on gut microbiota-targeted modalities include probiotics, prebiotics, and postbiotics [106]. Supplementation with the probiotic Lactobacillus casei or prebiotic inulin within pregnancy and lactation protected adult male rat progeny against hypertension programmed by a maternal high-fructose diet [39] or high-fat diet [121]. Another study indicated that maternal oligofructose therapy attenuated hepatic steatosis and insulin resistance induced in adult offspring born to dams received high-fat/high-sucrose diets [141]. We previously demonstrated that maternal 3,3-dimethyl1-butanol (an inhibitor of TMAO formation) treatment protects adult offspring against maternal high-fructose diet-induced hypertension, which was coincided with the reduction of TMAO levels [134]. Another report showed that maternal acetate supplementation was able to prevent the elevation of BP in adult rat offspring in a high-fructose diet model [36]. Although results from animal studies on microbiota-targeted reprogramming interventions in the prevention of MetS-related disorders are beneficial, we still do not know if these reprogramming effects are organ-specific, and to what extent if they are

\subsection{Dysregulated Nitrient-Sensing Signal}

Nutrient-sensing signals regulate whole-body metabolic homeostasis [142]. During fetal development, nutrient-sensing signals orchestrate fetal metabolism in response to maternal nutritional insults. Accordingly, disturbed nutrient-sensing signals in pregnancy have a unique role in the pathogenesis of MetS of developmental origins [143]. These signals include cyclic adenosine monophosphate (AMP)-activated protein kinase (AMPK), silent information regulator transcript (SIRT), peroxisome proliferator-activated receptors (PPARs), PPAR $\gamma$ coactivator- $1 \alpha$ (PGC-1 $\alpha$ ), and mammalian target of rapamycin (mTOR) pathways [144]. AMPK and SIRT1 can mediate phosphorylation and deacetylation of PGC$1 \alpha$, respectively [145], to control the expression of PPARs and their target genes. It is known that PPARs govern the expression of specific sets of target genes involved in hypertension of developmental origins [146], which can be driven by maternal nutritional insults.

Conversely, resveratrol, an AMPK activator, can mediate nutrient-sensing signals to activate expression of PPARs target genes and thereby reprogramming MetS-related programmed processes $[147,148]$. Additionally, AMPK activation by resveratrol treatment protects against insulin resistance and hyperlipidemia in a prenatal hypoxia/postnatal high-fat diet rat model [149]. Furthermore, our prior studies demonstrated that AMPK activation prevents the elevation of offspring's BP via regulation of nutrient-sensing signals in models of developmental hypertension programmed by a high-fructose diet [150] and a high-fat diet [151]. These observations establish a close connection between nutrientsensing signals and MetS of developmental origins.

\subsection{Glucocorticoid Programming}

Excess glucocorticoid signaling during pregnancy can disrupt the developmental trajectory of the fetus, resulting in long-term negative consequences [152]. Normally, fetal glucocorticoid levels are much lower than maternal levels due to the protection of placenta barrier via inactivation of glucocorticoid by the enzyme 11b-hydroxysteroid dehydrogenase type 2 (11b-HSD2) [153].

A number of suboptimal intrauterine conditions have linked to inhibit 11b-HSD2, leading to excess glucocorticoid in the fetal stage [152]. Furthermore, exogenous perinatal administration of dexamethasone has been linked to offspring hypertension $[70,71]$ and insulin resistance [72].

Using a prenatal dexamethasone rat model, we analyzed the renal transcriptome in the rat offspring using the whole genome RNA next generation sequencing in which hypertension of developmental origins was studied in adult male offspring [154]. A total of 431 renal transcripts were programmed by dexamethasone exposure at one and sixteen weeks of age. These findings suggest that glucocorticoid programming epigenetically regulated a great number of renal transcripts to contribute to hypertension of developmental origins. 
Despite detailed mechanisms that behind the epigenetic regulation of these genes and their roles in the programming processes toward development of hypertension remain unraveled, it is conceivable that glucocorticoid programming involves permanent and organ-specific changes in the expression of key genes, resulting in various features of MetS in adult life.

Notably, the placenta is closely interconnected to the aforementioned mechanisms, leading to fetal programming [155]. It is well known that the placenta transports maternal nutrients and oxygen to the fetus for growth and development. Amino acid concentrations in the fetal circulation are tightly controlled by the placenta, which is vital for normal fetal development and health in later life [156]. Placental oxidative stress can cause fetal programming, resulting in adult disease [157]. The placenta not only modulates nutrientsensing signals [143], but also 11b-HSD2 [153], thereby affecting fetal programming and the long-term health of the offspring. Although the existence and role of the placental microbiome remain inconclusive [158-160], it provides a possibility with regard to the alteration of placental microbiome as a possible reprogramming approach in MetS of developmental origins. Additional research on maternal risk factors together with placental programming's effect on Mets of developmental origins is urgently needed.

\section{Reprogramming Strategy}

With a greater understanding on the mechanisms underlying MetS programming, the development of mechanism-targeted strategies holds potential for reprogramming. So far, strategies to offset underlying mechanisms governing MetS that have been evaluated range from avoidance of risk factors, nutritional interventions, pharmacological therapies, exercise, to lifestyle modification $[6-9,81,161,162]$.

This review predominantly focuses on the pharmacological and nutritional interventions as reprogramming strategies to prevent MetS of developmental origins. Given that the difficulties in developing animal models displaying all characteristics of MetS, almost all pharmacological interventions into MetS of developmental origins have been investigated for their beneficial effects against some but not all components of MetS. A schematic summarizing the potential reprogramming interventions for MetS of developmental origins is presented in Figure 2. Each intervention will be discussed in turn.

\section{Reprogramming strategy}

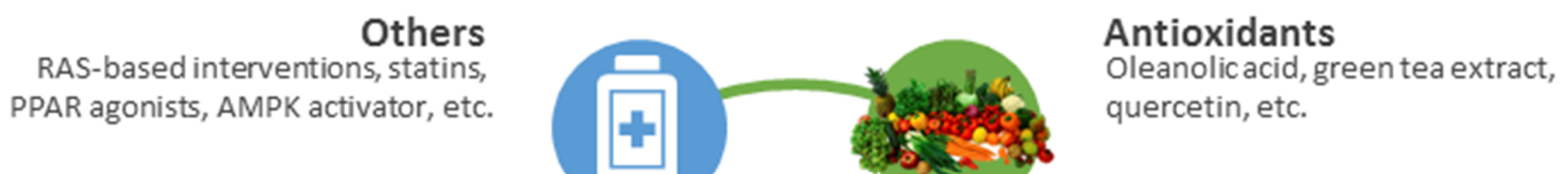

Amino acids

Citrulline, taurine, cysteine, branched chain amino acid, ect.

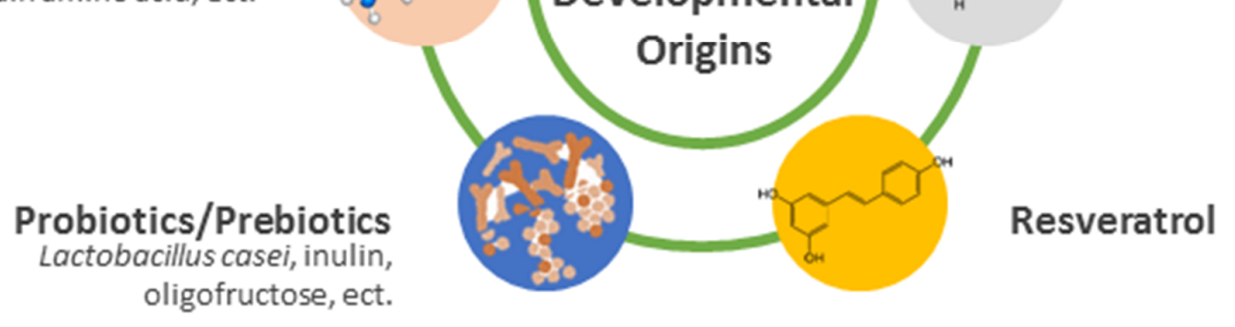

Figure 2. A summary of the currently available reprogramming interventions to prevent metabolic syndrome of developmental origins. RAS = renin-angiotensin system. PPAR = peroxisome proliferator-activated receptor. $\mathrm{AMPK}=\mathrm{cyclic}$ adenosine monophosphate-activated protein kinase. 


\subsection{Antioxidants}

Antioxidants can be classified as either enzymatic or non-enzymatic based on their activity [163]. Non-enzymatic antioxidants can be grouped into two categories: natural and synthetic [164]. Examples of natural nonenzymatic antioxidants are vitamin A, C, E, and flavonoids [163]. Most natural antioxidants come from plants. Polyphenols and carotenoids are the two main kinds of antioxidant phytochemicals.

Several phytochemicals with antioxidants have been reported to have beneficial effects against major hallmarks of MetS in adult offspring [161]. A previous report showed that early postnatal administration of oleanolic acid prevented dyslipidemia and insulin resistance in adult rat offspring $[165,166]$. Likewise, maternal green tea extract supplementation protected adult offspring against dyslipidemia and insulin resistance programmed by a high-fat diet [167]. Another study revealed that high-fat diets induced MetS phenotypes in adult offspring, including obesity, insulin resistance, and dyslipidemia, all of which can be protected by quercetin treatment during gestation and lactation [38]. Moreover, quercetin treatment during pregnancy and lactation reduced adipose tissue mass, improved insulin resistance, and restored dyslipidemia programmed by maternal high-fat diet $[38,168]$.

Although many vitamins and nature-derived antioxidants exert beneficial effects on oxidative stress-related disorders, there is little research about their reprogramming effects on MetS of developmental origins. Considering oxidative stress is a common mechanism behind MetS of developmental origins, there will be a growing need to better understand of the organ-specific mechanisms of various antioxidants in the prevention of various characteristics of MetS.

\subsection{Melatonin}

Melatonin, or N-acetyl-5-methoxytryptamine, is a pleiotropic hormone essential for pregnancy and fetal development [169]. Melatonin is an endogenous indoleamine mainly secreted by the pineal gland at night.

Melatonin is considered as a potential reprogramming intervention, and its benefits on hypertension have been supported by different models such as caloric restriction [170], NO deficiency [171], high-fructose diet [172], chronodisruption [60], and the glucocorticoid exposure model [71]. Additionally, maternal melatonin therapy protected adult rat offspring against obesity and dyslipidemia induced by prenatal dexamethasone administration and postnatal high-fat diet [173]. Notably, prior studies have demonstrated interplay between melatonin and the above-mentioned common mechanisms behind MetS of developmental origins, such as oxidative stress, aberrant RAS, nutrient-sensing signaling, and glucocorticoid programming [118]. These observations support the idea that melatonin may work in different ways to prevent MetS programming [174].

Melatonin is a relatively safe supplement in humans [175]. Although the uses of melatonin during gestation and lactation remain inconclusive, it has been clinically used for certain neonatal diseases [176]. Therefore, further translational research into the longterm MetS-related outcomes of perinatal melatonin use is urgently required.

\subsection{Resveratrol}

Resveratrol, or trans-3,5,4'-trihydroxystilbene, is a bioactive molecule with pleiotropic bioactivities [147]. The use of resveratrol as a nutraceutical has been evaluated in many disorders in both human trials and animal models $[177,178]$. More importantly, resveratrol has been considered as a reprogramming strategy for preventing MetS programming [179].

Early-life resveratrol treatment has been reported to protect offspring against hypertension $[64,150,151]$, hyperlipidemia $[37,180,181]$, obesity $[79,117,181]$, and insulin resistance $[117,182]$ in various developmental programming models. Resveratrol can act as an antioxidant against oxidative stress [182]. The implication of perinatal resveratrol therapy in alleviating oxidative stress-induced features of MetS is evidenced by the protection against hypertension in a high-fructose diet model, [156] and insulin resistance in a protein restriction model [117]. Additionally, resveratrol can mediate nutrient-sensing signals 
as it has been considered as a SIRT1 or AMPK activator [177]. We previously reported that AMPK activation by resveratrol prevented the elevation of offspring hypertension programmed by a high-fructose diet [150] and a high-fat diet [151].

\subsection{Probiotics/Prebiotics}

In view of the fact that gut microbiota dysbiosis is an important mechanism involved in the pathogenesis of developmentally programmed MetS, it seems logical to apply probiotics or prebiotics supplementation as a potential reprogramming intervention in regards to MetS of developmental origins. In clinical practice, the most commonly used gut microbiota-targeted interventions are probiotics and prebiotics. A recent systematic review demonstrated that probiotics intake in patients with MetS improved several features of MetS, including obesity, hypertension, glucose metabolism, and dyslipidemia in some studies [183]. However, limited information is available regarding their impact on the developmental origins of MetS in humans. Using rodent models induced by a maternal high-fructose diet [39] or high-fat diet [121], supplementation with the probiotic Lactobacillus casei or prebiotic inulin during gestation and lactation has shown to benefit hypertension in adult offspring. Another study revealed that maternal oligofructose supplementation attenuated insulin resistance and dyslipidemia induced by maternal high-fat/-sucrose diets [141].

There are other gut microbiota-related modalities applied to prevent CVD of developmental origins, as we reviewed elsewhere [106]. As a postbiotic, acetate supplementation within gestation and lactation was reported to protect offspring against high-fructose diet-induced hypertension, a major hallmark of MetS [134]. However, its reprogramming effects on other characteristics of MetS are awaiting further clarification. Future work in other gut microbiota-target modalities is needed to better identify ideal reprogramming interventions for the developmental origins of MetS.

\subsection{Amino Acids}

Amino acids can interfere with BP regulation [156], insulin signaling, and body composition [184]. As reviewed elsewhere, several amino acid supplementations during gestation and lactation have shown to benefit hypertension of developmental origins in various rodent models [156]. These amino acids include arginine [185], taurine [186], citrulline [187], cysteine [188], and branched chain amino acids (BCAAs) [189].

As citrulline can be converted to arginine, oral citrulline supplementation has been evaluated as an add-on therapy to increase NO production [190]. Apart from preventing hypertension, citrulline supplementation has also been shown to prevent hypertriglyceridemia and attenuate liver fat accumulation programmed by a maternal high-fructose diet [191]. N-acetylcysteine, a stable cysteine analog, has shown beneficial effects for CVD [192], the major complication of MetS. Although BCAA supplementation in pregnancy is able to prevent maternal caloric restriction-induced programmed hypertension [189], another study revealed that supplementation of BCAAs in rats fed with a high-fat diet contributes to development of obesity-associated insulin resistance [193]. Considering the complexity of amino acid metabolism between the mother and the fetus in pregnancy, we must elucidate the pathophysiologic roles of specific amino acids and their interactions in the developmental programming of MetS to avoid unintended long-term consequences.

\subsection{Others}

Currently, RAS inhibitors are the first-line pharmacological therapy for hypertension, which is a major hallmark of MetS [194]. There is a shortage of data with regard to MetS of developmental origin in humans. However, animal studies revealed several RAS-based interventions that benefit in protecting against programmed hypertension [104]. Much work is needed to elucidate whether these RAS-based interventions are also effective for other characteristics of MetS. 
Additionally, statins are a class of drugs recommended for dyslipidemia in MetS. In a maternal high-fat model, pravastatin administration protected offspring against obesity, hypertension [195], and dyslipidemia [196]. Further characterization of statins' reprograming effects against all features of MetS is required in other programming models.

Furthermore, some medications targeting nutrient-sensing signals have been shown to have a positive effect with regard to MetS. A growing body of evidence indicates that PPARs may serve as therapeutic targets for treating MetS-related diseases [197]. Several PPAR $\gamma$ agonists have shown beneficial effects on hypertension of developmental origins [146]; however, there is still limited information to decide the appropriate PPAR ligands for reprograming all characteristics of MetS in all models. Adenosine analog 5-aminoimidazole4-carboxamide-1-beta-D-ribofuranoside (AICAR), a direct AMPK activator, has been shown to improve glucose tolerance and lipid profiles, and to reduce BP in adult obese Zucker rats [198]. The reprogramming effect of AICAR on programmed hypertension has been observed in a maternal high-fat diet model [199]. It will be interesting to see whether AMPK activators show any benefits against other characteristics of MetS in various models of developmental programming.

\section{Conclusions and Future Perspectives}

This review highlighted the variety of adverse environmental factors during fetal development reported throughout the literature linking MetS of developmental origin, despite prior reviews that were mainly focused on nutritional imbalance [6-9].Reflecting current knowledge, our review also shed light on the fundamental mechanisms behind MetS of developmental origins at the molecular level. It opened a new window for preventing or delaying the onset of MetS via innovative reprogramming approaches.

Regardless of recent advances in establishing appropriate animal models for MetS of developmental origins, only a few models display the full manifestations of MetS. Although many reprogramming interventions have led to substantial progress in certain features of MetS in one model, attention must be paid to clarifying whether their effects are also beneficial for other MetS phenotypes; translation from one model into other models will be an additional challenge. Notably, almost no studies have taken a life course approach to determine all features of MetS in one experiment. In view of the fact that various characteristics of MetS appear throughout the course of a lifetime, most reprogramming interventions studied in a given time might be incomplete and this makes it difficult to predict their long-term effects. Meanwhile, even known reprogramming interventions appear promising, although the dose, timing and frequencies of intervention await identification and clinical validation.

Author Contributions: Conceptualization, C.-N.H. and Y.-L.T.; data curation, C.-N.H., C.-Y.H., W.-H.H. and Y.-L.T.; funding acquisition, Y.-L.T.; project administration, C.-N.H. and Y.-L.T.; writingoriginal draft, C.-N.H., C.-Y.H., W.-H.H. and Y.-L.T.; writing-review and editing, C.-N.H., C.-Y.H., W.-H.H. and Y.-L.T. All authors have read and agreed to the published version of the manuscript.

Funding: This research was funded by the Ministry of Science and Technology, Taiwan, grant MOST 110-2314-B182A-029, and Chang Gung Memorial Hospital, Kaohsiung, Taiwan, grants CFRPG8H0011, CMRPG8J0253, CORPG8J0121, CORPG8L0121, CORPG8L0261, and CORPG8L0301.

Institutional Review Board Statement: Not applicable.

Informed Consent Statement: Not applicable.

Data Availability Statement: All data are contained within the article.

Conflicts of Interest: The authors declare no conflict of interest. 


\section{References}

1. Alberti, K.G.; Eckel, R.H.; Grundy, S.M.; Zimmet, P.Z.; Cleeman, J.I.; Donato, K.A.; Fruchart, J.C.; James, W.P.; Loria, C.M.; Smith, S.C., Jr.; et al. Harmonizing the metabolic syndrome: A joint interim statement of the International Diabetes Federation Task Force on Epidemiology and Prevention; National Heart, Lung, and Blood Institute; American Heart Association; World Heart Federation; International Atherosclerosis Society; and International Association for the Study of Obesity. Circulation 2009, 120, 1640-1645.

2. Saklayen, M.G. The Global Epidemic of the Metabolic Syndrome. Curr. Hypertens. Rep. 2018, 20, 12. [CrossRef]

3. Zarocostas, J. Need to increase focus on non-communicable diseases in global health, says WHO. Br. Med. J. 2010, 341, c7065. [CrossRef] [PubMed]

4. Hanson, M. The birth and future health of DOHaD. J. Dev. Orig. Health Dis. 2015, 6, 434-437. [CrossRef]

5. Hanson, M.; Gluckman, P. Developmental origins of noncommunicable disease: Population and public health implications. Am. J. Clin. Nutr. 2011, 94, 1754S-1758S. [CrossRef] [PubMed]

6. McMillen, I.C.; Robinson, J.S. Developmental origins of the metabolic syndrome: Prediction, plasticity, and programming. Physiol. Rev. 2005, 85, 571-633. [CrossRef]

7. Gluckman, P.D.; Hanson, M.A. The developmental origins of the metabolic syndrome. Trends Endocrinol. Metab. 2004, 15, 183-187. [CrossRef]

8. Armitage, J.A.; Khan, I.Y.; Taylor, P.D.; Nathanielsz, P.W.; Poston, L. Developmental programming of the metabolic syndrome by maternal nutritional imbalance: How strong is the evidence from experimental models in mammals? J. Physiol. 2004, 561, 355-377. [CrossRef] [PubMed]

9. de Gusmão Correia, M.L.; Volpato, A.M.; Águila, M.B.; Mandarim-de-Lacerda, C.A. Developmental origins of health and disease: Experimental and human evidence of fetal programming for metabolic syndrome. J. Hum. Hypertens. 2012, 26, 405-419. [CrossRef] [PubMed]

10. Ma, N.; Hardy, D.B. The Fetal Origins of the Metabolic Syndrome: Can We Intervene? J. Pregnancy 2012, 2012, 482690. [CrossRef]

11. Tain, Y.L.; Joles, J.A. Reprogramming: A preventive strategy in hypertension focusing on the kidney. Int. J. Mol. Sci. 2015, 17, 23. [CrossRef]

12. Lumey, L.H. Reproductive outcomes in women prenatally exposed to undernutrition: A review of findings from the Dutch famine birth cohort. Proc. Nutr. Soc. 1998, 57, 129-135. [CrossRef]

13. Schulz, L.C. The Dutch Hunger Winter and the Developmental Origins of Health and Disease. Proc. Natl. Acad. Sci. USA 2010, 107, 16757-16758. [CrossRef]

14. Stanner, S.A.; Yudkin, J.S. Fetal programming and the Leningrad Siege study. Twin Res. 2001, 4, 287-292. [CrossRef]

15. Hult, M.; Tornhammar, P.; Ueda, P.; Chima, C.; Bonamy, A.K.; Ozumba, B.; Norman, M. Hypertension, diabetes and overweight: Looming legacies of the Biafran famine. PLOS ONE 2010, 5, e13582. [CrossRef] [PubMed]

16. Wang, G.; Chen, Z.; Bartell, T.; Wang, X. Early Life Origins of Metabolic Syndrome: The Role of Environmental Toxicants. Curr. Environ. Health Rep. 2014, 1, 78-89. [CrossRef]

17. Bo, S.; Cavallo-Perin, P.; Ciccone, G.; Scaglione, L.; Pagano, G. The metabolic syndrome in twins: A consequence of low birth weight or of being a twin? Exp. Clin. Endocrinol. Diabetes 2001, 109, 135-140. [CrossRef] [PubMed]

18. Vaag, A.; Poulsen, P. Twins in metabolic and diabetes research: What do they tell us? Curr. Opin. Clin. Nutr. Metab. Care 2007, 10, 591-596. [CrossRef]

19. Kelishadi, R.; Haghdoost, A.A.; Jamshidi, F.; Aliramezany, M.; Moosazadeh, M. Low birthweight or rapid catch-up growth: Which is more associated with cardiovascular disease and its risk factors in later life? A systematic review and cryptanalysis. Paediatr. Int. Child Health 2015, 35, 110-123. [CrossRef]

20. Hrudey, E.J.; Reynolds, R.M.; Oostvogels, A.J.; Brouwer, I.A.; Vrijkotte, T.G. The association between maternal 25-hydroxyvitamin D concentration during gestation and early childhood cardio-metabolic outcomes: Is there interaction with pre-pregnancy BMI? PLoS ONE 2015, 10, e0133313. [CrossRef]

21. Boney, C.M.; Verma, A.; Tucker, R.; Vohr, B.R. Metabolic syndrome in childhood: Association with birth weight, maternal obesity, and gestational diabetes mellitus. Pediatrics 2005, 115, e290-e296. [CrossRef]

22. Tam, W.H.; Ma, R.C.W.; Ozaki, R.; Li, A.M.; Chan, M.H.M.; Yuen, L.Y.; Lao, T.T.H.; Yang, X.; Ho, C.S.; Tutino, G.E.; et al. In utero exposure to maternal hyperglycemia increases childhood cardiometabolic risk in offspring. Diabetes Care 2017, 40, 679-686. [CrossRef] [PubMed]

23. Fraser, A.; Tilling, K.; Macdonald-Wallis, C.; Sattar, N.; Brion, M.J.; Benfield, L.; Ness, A.; Deanfield, J.; Hingorani, A.; Nelson, S.M.; et al. Association of maternal weight gain in pregnancy with offspring obesity and metabolic and vascular traits in childhood. Circulation 2010, 121, 2557-2564. [CrossRef] [PubMed]

24. Soubry, A. Epigenetics as a Driver of Developmental Origins of Health and Disease: Did We Forget the Fathers? Bioessays 2018, 40, 1700113. [CrossRef]

25. Eberle, C.; Kirchner, M.F.; Herden, R.; Stichling, S. Paternal metabolic and cardiovascular programming of their offspring: A systematic scoping review. PLoS ONE 2020, 15, e0244826. [CrossRef] [PubMed]

26. Tain, Y.L.; Hsu, C.N. Interplay between Oxidative Stress and Nutrient Sensing Signaling in the Developmental Origins of Cardiovascular Disease. Int. J. Mol. Sci. 2017, 18, 841. [CrossRef] 
27. Chong, E.; Yosypiv, I.V. Developmental programming of hypertension and kidney disease. Int. J. Nephrol. 2012, $2012,760580$. [CrossRef] [PubMed]

28. Hsu, C.N.; Tain, Y.L. Early Origins of Hypertension: Should Prevention Start Before Birth Using Natural Antioxidants? Antioxidants 2020, 9, 1034. [CrossRef]

29. Hsu, C.N.; Tain, Y.L. Animal Models for DOHaD Research: Focus on Hypertension of Developmental Origins. Biomedicines 2021, 9, 623. [CrossRef]

30. Tain, Y.L.; Hsieh, C.S.; Lin, I.C.; Chen, C.C.; Sheen, J.M.; Huang, L.T. Effects of maternal L-citrulline supplementation on renal function and blood pressure in offspring exposed to maternal caloric restriction: The impact of nitric oxide pathway. Nitric Oxide 2010, 23, 34-41. [CrossRef]

31. Franco Mdo, C.; Ponzio, B.F.; Gomes, G.N.; Gil, F.Z.; Tostes, R.; Carvalho, M.H.; Fortes, Z.B. Micronutrient prenatal supplementation prevents the development of hypertension and vascular endothelial damage induced by intrauterine malnutrition. Life Sci. 2009, 85, 327-333. [CrossRef] [PubMed]

32. Holemans, K.; Verhaeghe, J.; Dequeker, J.; Van Assche, F.A. Insulin sensitivity in adult female rats subjected to malnutrition during the perinatal period. J. Soc. Gynecol. Investig. 1996, 3, 71-77. [CrossRef]

33. Cambonie, G.; Comte, B.; Yzydorczyk, C.; Ntimbane, T.; Germain, N.; Lê, N.L.; Pladys, P.; Gauthier, C.; Lahaie, I.; Abran, D.; et al. Antenatal antioxidant prevents adult hypertension, vascular dysfunction, and microvascular rarefaction associated with in utero exposure to a low-protein diet. Am. J. Physiol. Regul. Integr. Comp. Physiol. 2007, 292, R1236-R1245. [CrossRef] [PubMed]

34. Ozanne, S.E.; Smith, G.D.; Tikerpae, J.; Hales, C.N. Altered regulation of hepatic glucose output in the male offspring of protein-malnourished rat dams. Am. J. Physiol. 1996, 270, E559-E564. [CrossRef] [PubMed]

35. Hsu, C.N.; Hou, C.Y.; Chang-Chien, G.P.; Lin, S.; Tain, Y.L. Maternal Garlic Oil Supplementation Prevents High-Fat Diet-Induced Hypertension in Adult Rat Offspring: Implications of H2S-Generating Pathway in the Gut and Kidneys. Mol. Nutr. Food Res. 2021, 65, e2001116. [CrossRef]

36. Tsai, T.A.; Tsai, C.K.; Huang, L.T.; Sheen, J.M.; Tiao, M.M.; Tain, Y.L.; Chen, C.C.; Lin, I.C.; Lai, Y.J.; Tsai, C.C.; et al. Maternal Resveratrol Treatment Re-Programs and Maternal High-Fat Diet-Induced Retroperitoneal Adiposity in Male Offspring. Int. J. Environ. Res. Public Health 2020, 17, 2780. [CrossRef] [PubMed]

37. Sheen, J.M.; Yu, H.R.; Tain, Y.L.; Tsai, W.L.; Tiao, M.M.; Lin, I.C.; Tsai, C.C.; Lin, Y.J.; Huang, L.T. Combined maternal and postnatal high-fat diet leads to metabolic syndrome and is effectively reversed by resveratrol: A multiple-organ study. Sci. Rep. 2018, 8 , 5607. [CrossRef]

38. Wu, Z.; Zhao, J.; Xu, H.; Lyv, Y.; Feng, X.; Fang, Y.; Xu, Y. Maternal quercetin administration during gestation and lactation decrease endoplasmic reticulum stress and related inflammation in the adult offspring of obese female rats. Eur. J. Nutr. 2014, 53, 1669-1683. [CrossRef]

39. Hsu, C.N.; Lin, Y.J.; Hou, C.Y.; Tain, Y.L. Maternal Administration of Probiotic or Prebiotic Prevents Male Adult Rat Offspring against Developmental Programming of Hypertension Induced by High Fructose Consumption in Pregnancy and Lactation. Nutrients 2018, 10, 1229. [CrossRef]

40. Chao, Y.M.; Tain, Y.L.; Leu, S.; Wu, K.L.; Lee, W.C.; Chan, J.Y. Developmental programming of the metabolic syndrome: Nextgeneration sequencing analysis of transcriptome expression in a rat model of maternal high fructose intake. Sheng Li Xue Bao 2016, 68, 557-567.

41. Saad, A.F.; Dickerson, J.; Kechichian, T.B.; Yin, H.; Gamble, P.; Salazar, A.; Patrikeev, I.; Motamedi, M.; Saade, G.R.; Costantine, M.M. High-fructose diet in pregnancy leads to fetal programming of hypertension, insulin resistance, and obesity in adult offspring. Am. J. Obstet. Gynecol. 2016, 215, 378.e1-378.e6. [CrossRef]

42. Yamada-Obara, N.; Yamagishi, S.I.; Taguchi, K.; Kaida, Y.; Yokoro, M.; Nakayama, Y.; Ando, R.; Asanuma, K.; Matsui, T.; Ueda, S.; et al. Maternal exposure to high-fat and high-fructose diet evokes hypoadiponectinemia and kidney injury in rat offspring. Clin. Exp. Nephrol. 2016, 20, 853-886. [CrossRef]

43. Li, M.; Reynolds, C.M.; Gray, C.; Patel, R.; Sloboda, D.M.; Vickers, M.H. Long-term effects of a maternal high-fat: High-fructose diet on offspring growth and metabolism and impact of maternal taurine supplementation. J. Dev. Orig. Health Dis. 2020, 11, 419-426. [CrossRef] [PubMed]

44. Bergel, E.; Belizán, J.M. A deficient maternal calcium intake during pregnancy increases blood pressure of the offspring in adult rats. BJOG 2002, 109, 540-545. [CrossRef]

45. Park, S.; Kang, S.; Kim, D.S. Severe calcium deficiency increased visceral fat accumulation, down-regulating genes associated with fat oxidation, and increased insulin resistance while elevating serum parathyroid hormone in estrogen-deficient rats. Nutr. Res. 2020, 73, 48-57. [CrossRef] [PubMed]

46. Tomat, A.; Elesgaray, R.; Zago, V.; Fasoli, H.; Fellet, A.; Balaszczuk, A.M.; Schreier, L.; Costa, M.A.; Arranz, C. Exposure to zinc deficiency in fetal and postnatal life determines nitric oxide system activity and arterial blood pressure levels in adult rats. $\mathrm{Br}$. $J$. Nutr. 2010, 104, 382-389. [CrossRef] [PubMed]

47. Jou, M.Y.; Philipps, A.F.; Lönnerdal, B. Maternal zinc deficiency in rats affects growth and glucose metabolism in the offspring by inducing insulin resistance postnatally. J. Nutr. 2010, 140, 1621-1627. [CrossRef]

48. Tare, M.; Emmett, S.J.; Coleman, H.A.; Skordilis, C.; Eyles, D.W.; Morley, R.; Parkington, H.C. Vitamin D insufficiency is associated with impaired vascular endothelial and smooth muscle function and hypertension in young rats. J. Physiol. 2011, 589, 4777-4786. [CrossRef] [PubMed] 
49. Zhang, H.; Chu, X.; Huang, Y.; Li, G.; Wang, Y.; Li, Y.; Sun, C. Maternal vitamin D deficiency during pregnancy results in insulin resistance in rat offspring, which is associated with inflammation and Ikb $\alpha$ methylation. Diabetologia 2014, 57, $2165-2172$. [CrossRef]

50. Wlodek, M.E.; Westcott, K.; Siebel, A.L.; Owens, J.A.; Moritz, K.M. Growth restriction before or after birth reduces nephron number and increases blood pressure in male rats. Kidney Int. 2008, 74, 187-195. [CrossRef]

51. Nüsken, K.D.; Dötsch, J.; Rauh, M.; Rascher, W.; Schneider, H. Uteroplacental insufficiency after bilateral uterine artery ligation in the rat: Impact on postnatal glucose and lipid metabolism and evidence for metabolic programming of the offspring by sham operation. Endocrinology 2008, 149, 1056-1063. [CrossRef] [PubMed]

52. Sherman, S.B.; Sarsour, N.; Salehi, M.; Schroering, A.; Mell, B.; Joe, B.; Hill, J.W. Prenatal androgen exposure causes hypertension and gut microbiota dysbiosis. Gut Microbes 2018, 9, 400-421. [CrossRef] [PubMed]

53. Zuchowski, Y.; Dalmasso, C.; Shawky, N.M.; Reckelhoff, J.F. Cardiometabolic consequences of maternal hyperandrogenemia in male offspring. Physiol. Rep. 2021, 9, e14941. [CrossRef] [PubMed]

54. Iqbal, W.; Ciriello, J. Effect of maternal chronic intermittent hypoxia during gestation on offspring growth in the rat. Am. J. Obstet. Gynecol. 2013, 209, 564.e1-564.e9. [CrossRef] [PubMed]

55. Wang, J.; Yin, N.; Deng, Y.; Wei, Y.; Huang, Y.; Pu, X.; Li, L.; Zheng, Y.; Guo, J.; Yu, J.; et al. Ascorbic Acid Protects against Hypertension through Downregulation of ACE1 Gene Expression Mediated by Histone Deacetylation in Prenatal InflammationInduced Offspring. Sci. Rep. 2016, 6, 39469. [CrossRef]

56. Tsosura, T.V.S.; Chiba, F.Y.; Mattera, M.S.L.C.; Pereira, R.F.; Cintra, L.T.A.; Conti, L.C.; Santos, R.M.D.; Mateus, J.H.P.; Garbin, C.A.S.; Sumida, D.H. Maternal apical periodontitis is associated with insulin resistance in adult offspring. Int. Endod. J. 2019, 52, 1040-1050. [CrossRef]

57. Tain, Y.L.; Lee, W.C.; Hsu, C.N.; Lee, W.C.; Huang, L.T.; Lee, C.T.; Lin, C.Y. Asymmetric dimethylarginine is associated with developmental programming of adult kidney disease and hypertension in offspring of streptozotocin-treated mothers. PLoS ONE 2013, 8, e55420.

58. Oliveira, A.C.; Andreotti, S.; Chimin, P.; Sertié, R.A.; Farias Tda, S.; Torres-Leal, F.L.; de Proença, A.R.; Campaña, A.B.; D’Avila, L.S.; Oliveira, K.A.; et al. Neonatal streptozotocin-induced diabetes in mothers promotes metabolic programming of adipose tissue in male rat offspring. Life Sci. 2015, 136, 151-156. [CrossRef]

59. Thaeomor, A.; Teangphuck, P.; Chaisakul, J.; Seanthaweesuk, S.; Somparn, N.; Roysommuti, S. Perinatal Taurine Supplementation Prevents Metabolic and Cardiovascular Effects of Maternal Diabetes in Adult Rat Offspring. Adv. Exp. Med. Biol. 2017, 975, 295-305.

60. Tain, Y.L.; Lin, Y.J.; Chan, J.Y.H.; Lee, C.T.; Hsu, C.N. Maternal melatonin or agomelatine therapy prevents programmed hypertension in male offspring of mother exposed to continuous light. Biol. Reprod. 2017, 97, 636-643. [CrossRef]

61. Ferreira, D.S.; Amaral, F.G.; Mesquita, C.C.; Barbosa, A.P.; Lellis-Santos, C.; Turati, A.O.; Santos, L.R.; Sollon, C.S.; Gomes, P.R.; Faria, J.A.; et al. Maternal melatonin programs the daily pattern of energy metabolism in adult offspring. PLoS ONE 2012, 7, e38795. [CrossRef] [PubMed]

62. Wei, Z.; Song, L.; Wei, J.; Chen, T.; Chen, J.; Lin, Y.; Xia, W.; Xu, B.; Li, X.; Chen, X.; et al. Maternal exposure to di-(2ethylhexyl)phthalate alters kidney development through the renin-angiotensin system in offspring. Toxicol. Lett. 2012, 212, 212-221. [CrossRef] [PubMed]

63. Rajagopal, G.; Bhaskaran, R.S.; Karundevi, B. Maternal di-(2-ethylhexyl) phthalate exposure alters hepatic insulin signal transduction and glucoregulatory events in rat F1 male offspring. J. Appl. Toxicol. 2019, 39, 751-763. [CrossRef]

64. Hsu, C.N.; Lin, Y.J.; Tain, Y.L. Maternal exposure to bisphenol A combined with high-fat diet-induced programmed hypertension in adult male rat offspring: Effects of resveratrol. Int. J. Mol. Sci. 2019, 20, 4382. [CrossRef]

65. Galyon, K.D.; Farshidi, F.; Han, G.; Ross, M.G.; Desai, M.; Jellyman, J.K. Maternal bisphenol A exposure alters rat offspring hepatic and skeletal muscle insulin signaling protein abundance. Am. J. Obstet. Gynecol. 2017, 216, 290.e1-290.e9. [CrossRef] [PubMed]

66. Gray, S.P.; Denton, K.M.; Cullen-McEwen, L.; Bertram, J.F.; Moritz, K.M. Prenatal exposure to alcohol reduces nephron number and raises blood pressure in progeny. J. Am. Soc. Nephrol. 2010, 21, 1891-1902. [CrossRef] [PubMed]

67. Nguyen, T.M.T.; Steane, S.E.; Moritz, K.M.; Akison, L.K. Prenatal alcohol exposure programmes offspring disease: Insulin resistance in adult males in a rat model of acute exposure. J. Physiol. 2019, 597, 5619-5637. [CrossRef] [PubMed]

68. Xiao, D.; Huang, X.; Li, Y.; Dasgupta, C.; Wang, L.; Zhang, L. Antenatal Antioxidant Prevents Nicotine-Mediated Hypertensive Response in Rat Adult Offspring. Biol. Reprod. 2015, 93, 66. [CrossRef]

69. Holloway, A.C.; Lim, G.E.; Petrik, J.J.; Foster, W.G.; Morrison, K.M.; Gerstein, H.C. Fetal and neonatal exposure to nicotine in Wistar rats results in increased beta cell apoptosis at birth and postnatal endocrine and metabolic changes associated with type 2 diabetes. Diabetologia 2005, 48, 2661-2666. [CrossRef]

70. Tain, Y.L.; Sheen, J.M.; Chen, C.C.; Yu, H.R.; Tiao, M.M.; Kuo, H.C.; Huang, L.T. Maternal citrulline supplementation prevents prenatal dexamethasone-induced programmed hypertension. Free Radic. Res. 2014, 48, 580-586. [CrossRef]

71. Chang, H.Y.; Tain, Y.L. Postnatal dexamethasone-induced programmed hypertension is related to the regulation of melatonin and its receptors. Steroids 2016, 108, 1-6. [CrossRef] [PubMed] 
72. Nyirenda, M.J.; Lindsay, R.S.; Kenyon, C.J.; Burchell, A.; Seckl, J.R. Glucocorticoid exposure in late gestation permanently programs rat hepatic phosphoenolpyruvate carboxykinase and glucocorticoid receptor expression and causes glucose intolerance in adult offspring. J. Clin. Investig. 1998, 101, 2174-2181. [CrossRef] [PubMed]

73. McMullen, S.; Mostyn, A. Animal models for the study of the developmental origins of health and disease. Proc. Nutr. Soc. 2009, 68, 306-320. [CrossRef]

74. Sengupta, P. The Laboratory Rat: Relating Its Age with Human's. Int. J. Prev. Med. 2013, 4, 624-630.

75. Hsu, C.N.; Tain, Y.L. The Double-Edged Sword Effects of Maternal Nutrition in the Developmental Programming of Hypertension. Nutrients 2018, 10, 1917. [CrossRef]

76. Langley-Evans, S.C. Critical differences between two low protein diet protocols in the programming of hypertension in the rat. Int. J. Food Sci. Nutr. 2000, 51, 11-17. [CrossRef] [PubMed]

77. Buettner, R.; Schölmerich, J.; Bollheimer, L.C. High-fat diets: Modeling the metabolic disorders of human obesity in rodents. Obesity 2007, 15, 798-808. [CrossRef]

78. Williams, L.; Seki, Y.; Vuguin, P.M.; Charron, M.J. Animal models of in utero exposure to a high fat diet: A review. Biochim. Biophys. Acta 2014, 1842, 507-519. [CrossRef]

79. Hsu, M.H.; Sheen, J.M.; Lin, I.C.; Yu, H.R.; Tiao, M.M.; Tain, Y.L.; Huang, L.T. Effects of Maternal Resveratrol on Maternal High-Fat Diet/Obesity with or without Postnatal High-Fat Diet. Int. J. Mol. Sci. 2020, 21, 3428. [CrossRef]

80. Tain, Y.L.; Lin, Y.J.; Sheen, J.M.; Yu, H.R.; Tiao, M.M.; Chen, C.C.; Tsai, C.C.; Huang, L.T.; Hsu, C.N. High Fat Diets Sex-Specifically Affect the Renal Transcriptome and Program Obesity, Kidney Injury, and Hypertension in the Offspring. Nutrients 2017, 9, 357. [CrossRef]

81. Lee, W.C.; Wu, K.L.H.; Leu, S.; Tain, Y.L. Translational insights on developmental origins of metabolic syndrome: Focus on fructose consumption. Biomed. J. 2018, 41, 96-101. [CrossRef] [PubMed]

82. Armengaud, J.B.; Yzydorczyk, C.; Siddeek, B.; Peyter, A.C.; Simeoni, U. Intrauterine growth restriction: Clinical consequences on health and disease at adulthood. Reprod. Toxicol. 2021, 99, 168-176. [CrossRef] [PubMed]

83. Bahri Khomami, M.; Joham, A.E.; Boyle, J.A.; Piltonen, T.; Silagy, M.; Arora, C.; Misso, M.L.; Teede, H.J.; Moran, L.J. Increased maternal pregnancy complications in polycystic ovary syndrome appear to be independent of obesity-A systematic review, meta-analysis, and meta-regression. Obes. Rev. 2019, 20, 659-674. [CrossRef]

84. Kalagiri, R.R.; Carder, T.; Choudhury, S.; Vora, N.; Ballard, A.R.; Govande, V.; Drever, N.; Beeram, M.R.; Uddin, M.N. Inflammation in Complicated Pregnancy and Its Outcome. Am. J. Perinatol. 2016, 33, 1337-1356. [CrossRef]

85. Saravanan, P.; Diabetes in Pregnancy Working Group; Maternal Medicine Clinical Study Group; Royal College of Obstetricians and Gynaecologists, UK. Gestational diabetes: Opportunities for improving maternal and child health. Lancet Diabetes Endocrinol. 2020, 8, 793-800. [CrossRef]

86. Zimmet, P.; Alberti, K.G.M.M.; Stern, N.; Bilu, C.; El-Osta, A.; Einat, H.; Kronfeld-Schor, N. The Circadian Syndrome: Is the Metabolic Syndrome and much more! J. Intern. Med. 2019, 286, 181-191. [CrossRef]

87. Lian, Y.; Yuan, Q.; Wang, G.; Tang, F. Association between sleep quality and metabolic syndrome: A systematic review and meta-analysis. Psychiatry Res. 2019, 274, 66-74. [CrossRef]

88. Scheer, F.A.; Hilton, M.F.; Mantzoros, C.S.; Shea, S.A. Adverse metabolic and cardiovascular consequences of circadian misalignment. Proc. Natl. Acad. Sci. USA 2009, 106, 4453-4458. [CrossRef]

89. Takahashi, J.S. Transcriptional architecture of the mammalian circadian clock. Nat. Rev. Genet. 2017, 18, 164-179. [CrossRef]

90. Sumová, A.; Bendová, Z.; Sládek, M.; El-Hennamy, R.; Laurinová, K.; Jindráková, Z.; Illnerová, H. Setting the biological time in central and peripheral clocks during ontogenesis. FEBS Lett. 2006, 580, 2836-2842. [CrossRef]

91. Reiter, R.J.; Tan, D.X.; Korkmaz, A.; Rosales-Corral, S.A. Melatonin and stable circadian rhythms optimize maternal, placental and fetal physiology. Hum. Reprod. Update 2014, 20, 293-307. [CrossRef] [PubMed]

92. Okatani, Y.; Okamoto, K.; Hayashi, K.; Wakatsuki, A.; Tamura, S.; Sagara, Y. Maternal-fetal transfer of melatonin in pregnant women near term. J. Pineal Res. 1998, 25, 129-134. [CrossRef]

93. Hsu, C.N.; Tain, Y.L. Light and Circadian Signaling Pathway in Pregnancy: Programming of Adult Health and Disease. Int. J. Mol. Sci. 2020, 21, 2232. [CrossRef]

94. Hsu, C.N.; Tain, Y.L. Adverse Impact of Environmental Chemicals on Developmental Origins of Kidney Disease and Hypertension. Front. Endocrinol. 2021, 12, 745716. [CrossRef]

95. Kirkley, A.G.; Sargis, R.M. Environmental endocrine disruption of energy metabolism and cardiovascular risk. Curr. Diabetes Rep. 2014, 14, 494. [CrossRef]

96. Slotkin, T.A. Cholinergic systems in brain development and disruption by neurotoxicants: Nicotine, environmental tobacco smoke, organophosphates. Toxicol. Appl. Pharmacol. 2004, 198, 132-151. [CrossRef] [PubMed]

97. Slabiak-Blaz, N.; Adamczak, M.; Gut, N.; Grajoszek, A.; Nyengaard, J.R.; Ritz, E.; Wiecek, A. Administration of cyclosporine a in pregnant rats-The effect on blood pressure and on the glomerular number in their offspring. Kidney Blood Press. Res. 2015, 40, 413-423. [CrossRef] [PubMed]

98. Hsu, C.N.; Chan, J.Y.H.; Wu, K.L.H.; Yu, H.R.; Lee, W.C.; Hou, C.Y.; Tain, Y.L. Altered Gut Microbiota and Its Metabolites in Hypertension of Developmental Origins: Exploring Differences between Fructose and Antibiotics Exposure. Int. J. Mol. Sci. 2021, 22, 2674. [CrossRef] [PubMed] 
99. Watkins, A.J.; Sinclair, K.D. Paternal low protein diet affects adult offspring cardiovascular and metabolic function in mice. Am. J. Physiol. Heart Circ. Physiol. 2014, 306, H1444-H1452. [CrossRef]

100. Masuyama, H.; Mitsui, T.; Eguchi, T.; Tamada, S.; Hiramatsu, Y. The effects of paternal high-fat diet exposure on offspring metabolism with epigenetic changes in the mouse adiponectin and leptin gene promoters. Am. J. Physiol. Endocrinol. Metab. 2016, 311, E236-E245. [CrossRef]

101. Li, X.; Shi, X.; Hou, Y.; Cao, X.; Gong, L.; Wang, H.; Li, J.; Li, J.; Wu, C.; Xiao, D.; et al. Paternal hyperglycemia induces transgenerational inheritance of susceptibility to hepatic steatosis in rats involving altered methylation on Ppar $\alpha$ promoter. Biochim. Biophys. Acta Mol. Basis Dis. 2019, 1865, 147-160. [CrossRef]

102. Thompson, L.P.; Al-Hasan, Y. Impact of oxidative stress in fetal programming. J. Pregnancy 2012, 2012, 582748. [CrossRef]

103. Bogdarina, I.; Welham, S.; King, P.J.; Burns, S.P.; Clark, A.J. Epigenetic modification of the renin-angiotensin system in the fetal programming of hypertension. Circ. Res. 2007, 100, 520-526. [CrossRef] [PubMed]

104. Hsu, C.N.; Tain, Y.L. Targeting the Renin-Angiotensin-Aldosterone System to Prevent Hypertension and Kidney Disease of Developmental Origins. Int. J. Mol. Sci. 2021, 22, 2298. [CrossRef]

105. Jašarević, E.; Bale, T.L. Prenatal and postnatal contributions of the maternal microbiome on offspring programming. Front. Neuroendocrinol. 2019, 55, 100797. [CrossRef] [PubMed]

106. Hsu, C.N.; Hou, C.Y.; Hsu, W.H.; Tain, Y.L. Cardiovascular Diseases of Developmental Origins: Preventive Aspects of Gut Microbiota-Targeted Therapy. Nutrients 2021, 13, 2290. [CrossRef]

107. Cottrell, E.C.; Seckl, J.R. Prenatal stress, glucocorticoids and the programming of adult disease. Front. Behav. Neurosci. 2009, 3, 19. [CrossRef]

108. Dennery, P.A. Oxidative stress in development: Nature or nurture? Free Radic. Biol. Med. 2010, 49, 1147-1151. [CrossRef] [PubMed]

109. Bruce, K.D.; Hanson, M.A. The developmental origins, mechanisms, and implications of metabolic syndrome. J. Nutr. 2010, 140, 648-652. [CrossRef]

110. Tain, Y.L.; Chan, J.Y.; Hsu, C.N. Maternal fructose intake affects transcriptome changes and programmed hypertension in offspring in later life. Nutrients 2016, 8, 757. [CrossRef]

111. Ching, R.H.; Yeung, L.O.; Tse, I.M.; Sit, W.H.; Li, E.T. Supplementation of bitter melon to rats fed a high-fructose diet during gestation and lactation ameliorates fructose-induced dyslipidemia and hepatic oxidative stress in male offspring. J. Nutr. 2011, 141, 1664e72. [CrossRef]

112. Rodriguez, L.; Otero, P.; Panadero, M.I.; Rodrigo, S.; Alvarez-Millan, J.J.; Bocos, C. Maternal fructose intake induces insulin resistance and oxidative stress in male, but not female, offspring. J. Nutr. Metab. 2015, 2015, 158091. [CrossRef] [PubMed]

113. Litvinova, L.; Atochin, D.N.; Fattakhov, N.; Vasilenko, M.; Zatolokin, P.; Kirienkova, E. Nitric oxide and mitochondria in metabolic syndrome. Front. Physiol. 2015, 6, 20. [CrossRef] [PubMed]

114. Huang, L.T.; Hsieh, C.S.; Chang, K.A.; Tain, Y.L. Roles of nitric oxide and asymmetric dimethylarginine in pregnancy and fetal programming. Int. J. Mol. Sci. 2012, 13, 14606-14622. [CrossRef] [PubMed]

115. Tain, Y.L.; Hsu, C.N. Toxic Dimethylarginines: Asymmetric Dimethylarginine (ADMA) and Symmetric Dimethylarginine (SDMA). Toxins 2017, 9, 92. [CrossRef]

116. Fan, E.; Zhang, L.; Jiang, S.; Bai, Y. Beneficial effects of resveratrol on atherosclerosis. J. Med. Food 2008, 11, 610-614. [CrossRef] [PubMed]

117. Vega, C.C.; Reyes-Castro, L.A.; Rodríguez-González, G.L.; Bautista, C.J.; Vázquez-Martínez, M.; Larrea, F.; Chamorro-Cevallos, G.A.; Nathanielsz, P.W.; Zambrano, E. Resveratrol partially prevents oxidative stress and metabolic dysfunction in pregnant rats fed a low protein diet and their offspring. J. Physiol. 2016, 594, 1483-1499. [CrossRef]

118. Hsu, C.N.; Huang, L.T.; Tain, Y.L. Perinatal Use of Melatonin for Offspring Health: Focus on Cardiovascular and Neurological Diseases. Int. J. Mol. Sci. 2019, 20, 5681. [CrossRef]

119. Putnam, K.; Shoemaker, R.; Yiannikouris, F.; Cassis, L.A. The renin-angiotensin system: A target of and contributor to dyslipidemias, altered glucose homeostasis, and hypertension of the metabolic syndrome. Am. J. Physiol. Heart Circ. Physiol. 2012, 302, H1219-H1230. [CrossRef]

120. Sahajpal, V.; Ashton, N. Increased glomerular angiotensin II binding in rats exposed to a maternal low protein diet in utero. J. Physiol. 2005, 563, 193-201. [CrossRef]

121. Hsu, C.N.; Hou, C.Y.; Chan, J.Y.H.; Lee, C.T.; Tain, Y.L. Hypertension Programmed by Perinatal High-Fat Diet: Effect of Maternal Gut Microbiota-Targeted Therapy. Nutrients 2019, 11, 2908. [CrossRef] [PubMed]

122. Hsu, C.N.; Wu, K.L.; Lee, W.C.; Leu, S.; Chan, J.Y.; Tain, Y.L. Aliskiren Administration during Early Postnatal Life Sex-Specifically Alleviates Hypertension Programmed by Maternal High Fructose Consumption. Front. Physiol. 2016, 7, 299. [CrossRef] [PubMed]

123. Grigore, D.; Ojeda, N.B.; Robertson, E.B.; Dawson, A.S.; Huffman, C.A.; Bourassa, E.A.; Speth, R.C.; Brosnihan, K.B.; Alexander B.T. Placental insufficiency results in temporal alterations in the renin angiotensin system in male hypertensive growth restricted offspring. Am. J. Physiol. Regul. Integr. Comp. Physiol. 2007, 293, R804-R811. [CrossRef]

124. Walton, S.L.; Bielefeldt-Ohmann, H.; Singh, R.R.; Li, J.; Paravicini, T.M.; Little, M.H.; Moritz, K.M. Prenatal hypoxia leads to hypertension, renal renin-angiotensin system activation and exacerbates salt-induced pathology in a sex-specific manner. Sci. Rep. 2017, 7, 8241. [CrossRef] 
125. Hao, X.Q.; Zhang, H.G.; Yuan, Z.B.; Yang, D.L.; Hao, L.Y.; Li, X.H. Prenatal exposure to lipopolysaccharide alters the intrarenal renin-angiotensin system and renal damage in offspring rats. Hypertens. Res. 2010, 33, 76-82. [CrossRef]

126. Chen, Y.W.; Chenier, I.; Tran, S.; Scotcher, M.; Chang, S.Y.; Zhang, S.L. Maternal diabetes programs hypertension and kidney injury in offspring. Pediatr. Nephrol. 2010, 25, 1319-1329. [CrossRef]

127. Te Riet, L.; van Esch, J.H.; Roks, A.J.; van den Meiracker, A.H.; Danser, A.H. Hypertension: Renin-angiotensin-aldosterone system alterations. Circ. Res. 2015, 116, 960-975. [CrossRef]

128. Bessa, A.S.M.; Jesus, É.F.; Nunes, A.D.C.; Pontes, C.N.R.; Lacerda, I.S.; Costa, J.M.; Souza, E.J.; Lino-Júnior, R.S.; Biancardi, M.F.; Dos Santos, F.C.A.; et al. Stimulation of the ACE2/Ang-(1-7)/Mas axis in hypertensive pregnant rats attenuates cardiovascular dysfunction in adult male offspring. Hypertens. Res. 2019, 42, 1883-1893. [CrossRef] [PubMed]

129. Tamburini, S.; Shen, N.; Wu, H.C.; Clemente, J.C. The microbiome in early life: Implications for health outcomes. Nat. Med. 2016, 22, 713-722. [CrossRef]

130. Wankhade, U.D.; Zhong, Y.; Kang, P.; Alfaro, M.; Chintapalli, S.V.; Thakali, K.M.; Shankar, K. Enhanced offspring predisposition to steatohepatitis with maternal high-fat diet is associated with epigenetic and microbiome alterations. PLOS ONE 2017, 12, e0175675. [CrossRef]

131. Guimarães, K.S.L.; Braga, V.A.; Noronha, S.I.S.R.; Costa, W.K.A.D.; Makki, K.; Cruz, J.C.; Brandão, L.R.; Chianca Junior, D.A.; Meugnier, E.; Leulier, F.; et al. Lactiplantibacillus plantarum WJL administration during pregnancy and lactation improves lipid profile, insulin sensitivity and gut microbiota diversity in dyslipidemic dams and protects male offspring against cardiovascular dysfunction in later life. Food Funct. 2020, 11, 8939-8950. [CrossRef]

132. De Oliveira, Y.; Cavalcante, R.G.S.; Cavalcanti Neto, M.P.; Magnani, M.; Braga, V.A.; de Souza, E.L.; de Brito Alves, J.L. Oral administration of Lactobacillus fermentum post-weaning improves the lipid profile and autonomic dysfunction in rat offspring exposed to maternal dyslipidemia. Food Funct. 2020, 11, 5581-5594. [CrossRef] [PubMed]

133. Wang, Z.; Zhao, Y. Gut microbiota derived metabolites in cardiovascular health and disease. Protein Cell $2018,9,416-431$. [CrossRef] [PubMed]

134. Hsu, C.N.; Chang-Chien, G.P.; Lin, S.; Hou, C.Y.; Tain, Y.L. Targeting on gut microbial metabolite trimethylamine-N-Oxide and short-chain fatty acid to prevent maternal high-fructose-diet-induced developmental programming of hypertension in adult male offspring. Mol. Nutr. Food Res. 2019, 63, e1900073. [CrossRef] [PubMed]

135. Khodor, S.A.; Reichert, B.; Shatat, I.F. The microbiome and blood pressure: Can microbes regulate our blood pressure? Front. Pediatr. 2017, 5, 138. [CrossRef]

136. Yang, T.; Richards, E.M.; Pepine, C.J.; Raizada, M.K. The gut microbiota and the brain-gut-kidney axis in hypertension and chronic kidney disease. Nat. Rev. Nephrol. 2018, 14, 442-456. [CrossRef]

137. Hsu, C.N.; Tain, Y.L. Developmental programming and reprogramming of hypertension and kidney disease: Impact of tryptophan metabolism. Int. J. Mol. Sci. 2020, 21, 8705. [CrossRef] [PubMed]

138. Chambers, E.S.; Preston, T.; Frost, G.; Morrison, D.J. Role of Gut Microbiota-Generated Short-Chain Fatty Acids in Metabolic and Cardiovascular Health. Curr. Nutr. Rep. 2018, 7, 198-206. [CrossRef] [PubMed]

139. Gatarek, P.; Kaluzna-Czaplinska, J. Trimethylamine N-oxide (TMAO) in human health. EXCLI J. 2021, 20, 301-319.

140. Agus, A.; Planchais, J.; Sokol, H. Gut Microbiota Regulation of Tryptophan Metabolism in Health and Disease. Cell Host Microbe 2018, 23, 716-724. [CrossRef] [PubMed]

141. Paul, H.A.; Collins, K.H.; Nicolucci, A.C.; Urbanski, S.J.; Hart, D.A.; Vogel, H.J.; Reimer, R.A. Maternal prebiotic supplementation reduces fatty liver development in offspring through altered microbial and metabolomic profiles in rats. FASEB J. 2019, 33, 5153-5167. [CrossRef] [PubMed]

142. Smith, R.L.; Soeters, M.R.; Wüst, R.C.I.; Houtkooper, R.H. Metabolic Flexibility as an Adaptation to Energy Resources and Requirements in Health and Disease. Endocr. Rev. 2018, 39, 489-517. [CrossRef] [PubMed]

143. Jansson, T.; Powell, T.L. Role of placental nutrient sensing in developmental programming. Clin. Obstet. Gynecol. 2013, 56, 591-601. [CrossRef]

144. Efeyan, A.; Comb, W.C.; Sabatini, D.M. Nutrient-sensing mechanisms and pathways. Nature 2015, 517, 302-310. [CrossRef] [PubMed]

145. Finck, B.N.; Kelly, D.P. Peroxisome proliferator-activated receptor gamma coactivator-1 (PGC-1) regulatory cascade in cardiac physiology and disease. Circulation 2007, 115, 2540-2548. [CrossRef]

146. Tain, Y.L.; Hsu, C.N.; Chan, J.Y. PPARs Link Early Life Nutritional insults to later programmed hypertension and metabolic syndrome. Int. J. Mol. Sci. 2015, 17, 20. [CrossRef]

147. Kulkarni, S.S.; Cantó, C. The molecular targets of resveratrol. Biochim. Biophys. Acta 2015, 1852, 1114-1123. [CrossRef]

148. Hsu, C.N.; Tain, Y.L. Preventive Aspects of Early Resveratrol Supplementation in Cardiovascular and Kidney Disease of Developmental Origins. Int. J. Mol. Sci. 2021, 22, 4210. [CrossRef]

149. Shah, A.; Reyes, L.M.; Morton, J.S.; Fung, D.; Schneider, J.; Davidge, S.T. Effect of resveratrol on metabolic and cardiovascular function in male and female adult offspring exposed to prenatal hypoxia and a high-fat diet. J. Physiol. 2016, 594, 1465-1482. [CrossRef]

150. Tain, Y.L.; Lee, W.C.; Wu, K.L.H.; Leu, S.; Chan, J.Y.H. Resveratrol Prevents the Development of Hypertension Programmed by Maternal Plus Post-Weaning High-Fructose Consumption Through Modulation of Oxidative Stress, Nutrient-Sensing Signals, and Gut Microbiota. Mol. Nutr. Food Res. 2018, 62, e1800066. [CrossRef] 
151. Tain, Y.L.; Lin, Y.J.; Sheen, J.M.; Lin, I.C.; Yu, H.R.; Huang, L.T.; Hsu, C.N. Resveratrol prevents the combined maternal plus post weaning high-fat-diets-induced hypertension in male offspring. J. Nutr. Biochem. 2017, 48, 120-127. [CrossRef] [PubMed]

152. Moisiadis, V.G.; Matthews, S.G. Glucocorticoids and fetal programming part 1: Outcomes. Nat. Rev. Endocrinol. 2014, 10, 391-402. [CrossRef] [PubMed]

153. Campbell, A.L.; Murphy, B.E. The maternal-fetal cortisol gradient during pregnancy and at delivery. J. Clin. Endocrinol. Metab. 1977, 45, 435-440. [CrossRef]

154. Sheen, J.M.; Yu, H.R.; Tiao, M.M.; Chen, C.C.; Huang, L.T.; Chang, H.Y.; Tain, Y.L. Prenatal dexamethasone-induced programmed hypertension and renal programming. Life Sci. 2015, 132, 41-48. [CrossRef] [PubMed]

155. Sferruzzi-Perri, A.N.; Camm, E.J. The Programming Power of the Placenta. Front. Physiol. 2016, 7, 33. [CrossRef]

156. Hsu, C.N.; Tain, Y.L. Amino Acids and Developmental Origins of Hypertension. Nutrients 2020, 12, 1763. [CrossRef]

157. Wu, F.; Tian, F.J.; Lin, Y. Oxidative Stress in Placenta: Health and Diseases. BioMed Res. Int. 2015, 2015, 293271. [CrossRef]

158. Aagaard, K.; Ma, J.; Antony, K.M.; Ganu, R.; Petrosino, J.; Versalovic, J. The placenta harbors a unique microbiome. Sci. Transl. Med. 2014, 6, 237ra65. [CrossRef] [PubMed]

159. de Goffau, M.C.; Lager, S.; Sovio, U.; Gaccioli, F.; Cook, E.; Peacock, S.J.; Parkhill, J.; Charnock-Jones, D.S.; Smith, G.C.S. Human placenta has no microbiome but can contain potential pathogens. Nature 2019, 572, 329-334. [CrossRef]

160. Olaniyi, K.S.; Moodley, J.; Mahabeer, Y.; Mackraj, I. Placental Microbial Colonization and Its Association with Pre-eclampsia. Front. Cell. Infect. Microbiol. 2020, 10, 413. [CrossRef] [PubMed]

161. Ibrahim, K.G.; Adeshina, K.A.; Bello, M.B.; Malami, I.; Abubakar, B.; Abubakar, M.B.; Imam, M.U. Prophylactic Use of Natural Products against Developmentally Programmed Metabolic Syndrome. Planta Med. 2021. [CrossRef]

162. Hsu, C.N.; Tain, Y.L. The First Thousand Days: Kidney Health and Beyond. Healthcare 2021, 9, 1332. [CrossRef] [PubMed]

163. Pisoschi, A.M.; Pop, A. The role of antioxidants in the chemistry of oxidative stress: A review. Eur. J. Med. Chem. 2015, 97, 55-74. [CrossRef]

164. Nimse, S.B.; Palb, D. Free radicals, natural antioxidants, and their reaction mechanisms. RSC Adv. 2015, 5, 27986-28006. [CrossRef]

165. Matumba, M.G.; Ayeleso, A.O.; Nyakudya, T.; Erlwanger, K.; Chegou, N.N.; Mukwevho, E. Long-term impact of neonatal intake of oleanolic acid on the expression of AMP-activated protein kinase, adiponectin and inflammatory cytokines in rats fed with a high fructose diet. Nutrients 2019, 11, 226. [CrossRef]

166. Nyakudya, T.T.; Mukwevho, E.; Erlwanger, K.H. The protective effect of neonatal oral administration of oleanolic acid against the subsequent development of fructose-induced metabolic dysfunction in male and female rats. Nutr. Metab. 2019, 15, 82. [CrossRef]

167. Li, S.; Tse, I.M.Y.; Li, E.T.S. Maternal green tea extract supplementation to rats fed a high-fat diet ameliorates insulin resistance in adult male offspring. J. Nutr. Biochem. 2012, 23, 1655-1660. [CrossRef] [PubMed]

168. Zhou, L.; Xiao, X.; Zhang, Q.; Zheng, J.; Deng, M. Maternal genistein intake mitigates the deleterious effects of high-fat diet on glucose and lipid metabolism and modulates gut microbiota in adult life of male mice. Front. Physiol. 2019, 10, 985. [CrossRef] [PubMed]

169. Tamura, H.; Nakamura, Y.; Terron, M.P.; Flores, L.J.; Manchester, L.C.; Tan, D.X.; Sugino, N.; Reiter, R.J. Melatonin and pregnancy in the human. Reprod. Toxicol. 2008, 25, 291-303. [CrossRef] [PubMed]

170. Tain, Y.L.; Huang, L.T.; Hsu, C.N.; Lee, C.T. Melatonin therapy prevents programmed hypertension and nitric oxide deficiency in offspring exposed to maternal caloric restriction. Oxid. Med. Cell. Longev. 2014, 2014, 283180. [CrossRef]

171. Tain, Y.L.; Lee, C.T.; Chan, J.Y.; Hsu, C.N. Maternal melatonin or N-acetylcysteine therapy regulates hydrogen sulfide-generating pathway and renal transcriptome to prevent prenatal N(G)-Nitro-L-arginine-methyl ester (L-NAME)-induced fetal programming of hypertension in adult male offspring. Am. J. Obstet. Gynecol. 2016, 215, 636. [CrossRef] [PubMed]

172. Tain, Y.L.; Leu, S.; Wu, K.L.; Lee, W.C.; Chan, J.Y. Melatonin prevents maternal fructose intake-induced programmed hypertension in the offspring: Roles of nitric oxide and arachidonic acid metabolites. J. Pineal Res. 2014, 57, 80-89. [CrossRef] [PubMed]

173. Tsai, C.C.; Lin, Y.J.; Yu, H.R.; Sheen, J.M.; Tain, Y.L.; Huang, L.T.; Tiao, M.M. Melatonin alleviates liver steatosis induced by prenatal dexamethasone exposure and postnatal high-fat diet. Exp. Ther. Med. 2018, 16, 917-924. [CrossRef] [PubMed]

174. Tain, Y.L.; Huang, L.T.; Hsu, C.N. Developmental Programming of Adult Disease: Reprogramming by Melatonin? Int. J. Mol. Sci. 2017, 18, 426. [CrossRef]

175. Andersen, L.P.; Gögenur, I.; Rosenberg, J.; Reiter, R.J. The Safety of Melatonin in Humans. Clin. Drug Investig. 2016, 36, 169-175. [CrossRef]

176. Chen, Y.C.; Tain, Y.L.; Sheen, J.M.; Huang, L.T. Melatonin utility in neonates and children. J. Formos. Med. Assoc. 2012, 111, 57-66. [CrossRef]

177. Diaz-Gerevini, G.T.; Repossi, G.; Dain, A.; Tarres, M.C.; Das, U.N.; Eynard, A.R. Beneficial action of resveratrol: How and why? Nutrition 2016, 32, 174-178. [CrossRef]

178. Singh, A.P.; Singh, R.; Verma, S.S.; Rai, V.; Kaschula, C.H.; Maiti, P.; Gupta, S.C. Health benefits of resveratrol: Evidence from clinical studies. Med. Res. Rev. 2019, 39, 1851-1891. [CrossRef]

179. Tain, Y.L.; Hsu, C.N. Developmental Programming of the Metabolic Syndrome: Can We Reprogram with Resveratrol? Int. J. Mol. Sci. 2018, 19, 2584. [CrossRef]

180. Zou, T.; Chen, D.; Yang, Q.; Wang, B.; Zhu, M.J.; Nathanielsz, P.W.; Du, M. Resveratrol supplementation of high-fat diet-fed pregnant mice promotes brown and beige adipocyte development and prevents obesity in male offspring. J. Physiol. 2017, 595, 1547-1562. [CrossRef] 
181. Ros, P.; Díaz, F.; Freire-Regatillo, A.; Argente-Arizón, P.; Barrios, V.; Argente, J.; Chowen, J.A. Resveratrol Intake during Pregnancy and Lactation Modulates the Early Metabolic Effects of Maternal Nutrition Differently in Male and Female Offspring. Endocrinology 2018, 159, 810-825. [CrossRef] [PubMed]

182. Dolinsky, V.W.; Rueda-Clausen, C.F.; Morton, J.S.; Davidge, S.T.; Dyck, J.R. Continued postnatal administration of resveratrol prevents diet-induced metabolic syndrome in rat offspring born growth restricted. Diabetes 2011, 60, 2274-2284. [CrossRef]

183. Tenorio-Jiménez, C.; Martínez-Ramírez, M.J.; Gil, Á.; Gómez-Llorente, C. Effects of Probiotics on Metabolic Syndrome: A Systematic Review of Randomized Clinical Trials. Nutrients 2020, 12, 124. [CrossRef] [PubMed]

184. Simonson, M.; Boirie, Y.; Guillet, C. Protein, amino acids and obesity treatment. Rev. Endocr. Metab. Disord. 2020, 21, 341-353. [CrossRef]

185. Koeners, M.P.; Racasan, S.; Koomans, H.A.; Joles, J.A.; Braam, B. Nitric oxide, superoxide and renal blood flow autoregulation in SHR after perinatal L-arginine and antioxidants. Acta Physiol. 2007, 190, 329-338. [CrossRef] [PubMed]

186. Roysommuti, S.; Lerdweeraphon, W.; Malila, P.; Jirakulsomchok, D.; Wyss, J.M. Perinatal taurine alters arterial pressure control and renal function in adult offspring. Adv. Exp. Med. Biol. 2009, 643, 145-156. [PubMed]

187. Tain, Y.L.; Huang, L.T.; Lee, C.T.; Chan, J.Y.; Hsu, C.N. Maternal citrulline supplementation prevents prenatal $\mathrm{N}^{\mathrm{G}}$-nitro-l-argininemethyl ester (L-NAME)-induced programmed hypertension in rats. Biol. Reprod. 2015, 92, 7. [CrossRef]

188. Hsu, C.N.; Lin, Y.J.; Lu, P.C.; Tain, Y.L. Early supplementation of D-cysteine or L-cysteine prevents hypertension and kidney damage in spontaneously hypertensive rats exposed to high-salt intake. Mol. Nutr. Food Res. 2018, 62, 2. [CrossRef]

189. Fujii, T.; Yura, S.; Tatsumi, K.; Kondoh, E.; Mogami, H.; Fujita, K.; Kakui, K.; Aoe, S.; Itoh, H.; Sagawa, N.; et al. Branched-chain amino acid supplemented diet during maternal food restriction prevents developmental hypertension in adult rat offspring. $J$. Dev. Orig. Health Dis. 2011, 2, 176-183. [CrossRef]

190. Cynober, L.; Moinard, C.; De Bandt, J.P. The 2009 ESPEN Sir David Cuthbertson. Citrulline: A new major signaling molecule or just another player in the pharmaconutrition game? Clin. Nutr. 2010, 29, 545-551. [CrossRef]

191. Jegatheesan, P.; Beutheu, S.; Ventura, G.; Sarfati, G.; Nubret, E.; Kapel, N.; Waligora-Dupriet, A.J.; Bergheim, I.; Cynober, L.; De-Bandt, J.P. Effect of specific amino acids on hepatic lipid metabolism in fructose-induced non-alcoholic fatty liver disease. Clin. Nutr. 2016, 35, 175-182. [CrossRef] [PubMed]

192. Dludla, P.V.; Dias, S.C.; Obonye, N.; Johnson, R.; Louw, J.; Nkambule, B.B. A Systematic Review on the Protective Effect of N-Acetyl Cysteine against Diabetes-Associated Cardiovascular Complications. Am. J. Cardiovasc. Drugs 2018, 18, $283-298$. [CrossRef]

193. Newgard, C.B.; An, J.; Bain, J.R.; Muehlbauer, M.J.; Stevens, R.D.; Lien, L.F.; Haqq, A.M.; Shah, S.H.; Arlotto, M.; Slentz, C.A.; et al. A branched-chain amino acid-related metabolic signature that differentiates obese and lean humans and contributes to insulin resistance. Cell Metab. 2009, 9, 311-326. [CrossRef] [PubMed]

194. Rask Larsen, J.; Dima, L.; Correll, C.U.; Manu, P. The pharmacological management of metabolic syndrome. Expert Rev. Clin. Pharmacol. 2018, 11, 397-410. [CrossRef] [PubMed]

195. Elahi, M.M.; Cagampang, F.R.; Ohri, S.K.; Hanson, M.A. Long-term statin administration to dams on high-fat diet protects not only them but also their offspring from cardiovascular risk. Ann. Nutr. Metab. 2013, 62, 250-256. [CrossRef] [PubMed]

196. Elahi, M.M.; Cagampang, F.R.; Anthony, F.W.; Curzen, N.; Ohri, S.K.; Hanson, M.A. Statin treatment in hypercholesterolemic pregnant mice reduces cardiovascular risk factors in their offspring. Hypertension 2008, 51, 939-944. [CrossRef] [PubMed]

197. Monsalve, F.A.; Pyarasani, R.D.; Delgado-Lopez, F.; Moore-Carrasco, R. Peroxisome proliferator-activated receptor targets for the treatment of metabolic diseases. Mediat. Inflamm. 2013, 2013, 549627. [CrossRef] [PubMed]

198. Buhl, E.S.; Jessen, N.; Pold, R.; Ledet, T.; Flyvbjerg, A.; Pedersen, S.B.; Pedersen, O.; Schmitz, O.; Lund, S. Long-term AICAR administration reduces metabolic disturbances and lowers blood pressure in rats displaying features of the insulin resistance syndrome. Diabetes 2002, 51, 2199-2206. [CrossRef]

199. Tsai, W.L.; Hsu, C.N.; Tain, Y.L. Whether AICAR in Pregnancy or Lactation Prevents Hypertension Programmed by High Saturated Fat Diet: A Pilot Study. Nutrients 2020, 12, 448. [CrossRef] 